\title{
Evidence of late-Holocene mud-volcanic eruptions in the Modena foothills (northern Italy)
}

\author{
Lisa Borgatti, ' (D) Bosi Giovanna, ${ }^{2}$ Bracci Antonio Edoardo, ${ }^{3}$ \\ Cremonini Stefano, ${ }^{4}$ Falsone Gloria, ${ }^{5}$ Guandalini Francesca, ${ }^{6}$ \\ Labate Donato, 7 Mainardi Giuseppe, ${ }^{3}$ Martinelli Giovanni, ${ }^{8,9}$ \\ Montecchi Maria Chiara ${ }^{2}$ and Pieraccini Diego ${ }^{3}$
}

\begin{abstract}
Among natural hazards, mud volcanoes can damage property and infrastructures and affect hillslope evolution at different spatial and temporal scales. The results of 10-year-long multidisciplinary investigations performed on a Roman-age archaeological site, La Rovina di Montegibbio, are presented, showing a peculiar example of mutual interplay between human settlement and geological forcing in the mud-volcanic environment. The site ( $350 \mathrm{~m}$ a.s.l.) lies at the termination of the upper Secchia River catchment, near the town of Sassuolo (Modena Province). Here, a 4-km-long mud volcano belt borders the Apennines chain front, comprising one of the most prominent mud volcanoes of Italy (Salsa di Montegibbio), and the still-active chain hinge tectonics gives origin to gas and oil seeps. Based on geological, geoarchaeological, palaeobotanical, geochemical, geophysical records and analytical data, we unravel the onset, the evolution and the abandonment of the settlement in relation to the existence of a previously unknown mud volcano, belonging to the larger Montegibbio mud volcano system. The damages affecting the Roman-age buildings record the ground deformations in the context of mud volcano tectonics. In particular, the pattern of faults set buried under the archaeological site is shown and compared with that of the main mud volcano conduit. At least two Roman-age eruptive episodes have been recorded, whose ejected muds are geochemically characterized. The first recorded eruption must be regarded as the reason for the initial location and function of the sacred ancient settlement. The final site abandonment was because of subsequent severe ground deformations affecting the hillslope as a consequence of mud volcano activity.
\end{abstract}

\section{Keywords}

geoarchaeology, geochemistry, Minerva goddess, Montegibbio, mud volcano, northern Apennines

Received 3 January 2018; revised manuscript accepted 3 January 2019

\section{Introduction}

The abandonment of human settlements as a consequence of natural catastrophic events has been recorded worldwide ever since prehistoric times: volcanic eruptions (Minoan Santorini), earthquakes (Stewart and Piccardi, 2017) and/or tsunamis (New Zealand coast), global climate changes and related geoenvironmental changes (Classic Mayan collapse). In Italy, volcanic eruptions induced the destruction of Pompei and Ercolano (Luongo et al., 2003). Landslides led to the abandonment of Civita di Bagnoregio (Del Monaco et al., 2009) and of the Rossano di Vaglio sanctuary (Sdao and Simeone, 2007). Seismic activity caused faulting in two important Italian archaeological sites (Cinti et al., 2015; Galadini and Galli, 1999). Floods influenced urban settlements in the Po River plain (Cremonini et al., 2013). Mud volcanoes are geological structures not of magmatic origin but able to erupt liquid, gaseous and clayey phases by a main vertical conduit, eventually surrounded by other minor conduits located nearby (Capozzi and Picotti, 2002; Hovland et al., 1997; Planke et al., 2003). Among natural hazards, mud volcanoes can damage property and infrastructure and affect hillslope evolution. Recently, lists and maps of active mud volcanoes in the world (e.g. Mazzini and Etiope, 2017) have been prepared, along with detailed descriptions of specific mud-volcanic areas (Italy, Romania, Azerbaijan, Ukraine). Manga and Bonini (2012) compiled a catalogue of historic mud-volcanic eruptions that occurred in the northern Apennines during the past millennium. The integration of the inventory with field surveys and analytical data allowed

'Dipartimento di Ingegneria Civile, Chimica,Ambientale e dei Materiali DICAM, ALMA MATER STUDIORUM Università di Bologna, Italy ${ }^{2}$ Dipartimento di Scienze della Vita, Università di Modena e Reggio Emilia, Italy

${ }^{3}$ Geoexploration, Italy

${ }^{4}$ Dipartimento Scienze Biologiche Geologiche Ambientali BiGeA, ALMA MATER STUDIORUM Università di Bologna, Italy

${ }^{5}$ Dipartimento di Scienze Agrarie DipSA, ALMA MATER STUDIORUM Università di Bologna, Italy

${ }^{6}$ ArcheoModena, Professional Archaeologist Associate Studio, Italy ${ }^{7}$ Soprintendenza Archeologia, Belle Arti, Paesaggio per le città di Bologna, Modena, Reggio Emilia e Ferrara, Italy ${ }^{8}$ ARPAE Environmental Protection Agency, Emilia Romagna Region, Department of Reggio Emilia, Italy

${ }^{9}$ Key Laboratory of Petroleum Resources, Gansu Province, Institute of Geology and Geophysics, Chinese Academy of Sciences, Lanzhou, P.R. China

\section{Corresponding author:}

Martinelli Giovanni, ARPAE Environmental Protection Agency, Emilia Romagna Region, Department of Reggio Emilia, Via Amendola 2, Reggio Emilia, 42100, Italy and Key Laboratory of Petroleum Resources, Gansu Province, Institute of Geology and Geophysics, Chinese Academy of Sciences, Lanzhou 730000, P.R. China.

Email: giovanni.martinelli15@gmail.com 
past eruption rates to be inferred as at least a few orders of magnitude greater than at present (Manga and Bonini, 2012). Other recent studies have remarked on the relationships among mud volcanoes, seismic activity (Lupi et al., 2015) and the related geodynamic setting (Martinelli and Panahi, 2005).

Despite the rich literature concerning mud volcanoes, little information about the stratigraphic features of mud-volcanic environments is available, mainly because of the lack of suitable markers dating before the year $1000 \mathrm{AD}$.

In this context, we illustrate a distinctive opportunity offered by an archaeological excavation and developed as a comprehensive geological investigation. Roman-age sanctuaries devoted to the goddess Minerva and built near water springs are well known in Italy (e.g. Bruno, 2012; Rossi, 2010), but that of La Rovina di Montegibbio (Guandalini, 2009) is the sole Minerva shrine located in the core of a mud-volcanic belt system in the northern Apennine chain fringe in Italy. A 10-year-long multidisciplinary investigation was carried out with the aim of describing the slopescale deformation and mudflow phenomena preserved in this archaeological site (Figure 1a). For the first time, previously unknown mud-volcanic activity that occurred during the lateHolocene is recognized as the ultimate cause of the onset and abandonment of the settlement.

\section{Geological and geomorphological setting}

The La Rovina di Montegibbio site lies at an elevation of $350 \mathrm{~m}$ a.s.l. on a small catchment divide near the town of Sassuolo (northern Italy), where the Secchia River valley intersects the frontal hinge of the Apennines chain (Figure 1). Small remnants of terraced landforms exist at various elevations up to the divide $(170,230 / 240,270,300$, and 340/350 m a.s.1.), some of which can be correlated to the main river system terrace dating to the middle- and late-Pleistocene (Gasperi et al., 2005). In some places atop these terraces, a reddish Alfisol, showing an average soil profile A-Bw-Bt-Bk-C (Cremaschi, 1979; Cremonini et al., 2012; Gasperi et al., 2005), represents a widespread stratigraphic marker that developed during the Bölling chronozone (15-14 ky BP). Its alteration profile can reach $1.5-2 \mathrm{~m}$ in thickness, but it is usually less than $1.5 \mathrm{~m}$ on the highest terraces and hilltops, mainly because of laminar erosion. The highly deformed Tertiary geological units, consisting mainly of grey or whitish-grey marls (Figure 1c), crop out along an anti-Apenninic direction owing to multiple buried tectonic lateral ramps (Oppo et al., 2013). Very close to the study site, an abrupt, linear morphologic boundary exists between the tectonized pre-Pliocene units and the gently dipping clayey Pliocene marine deposits (Figure 1c). Special attention must be paid to the silty-clayey Colombacci Formation (FCO) of Messinian age that in places ends with an upper, characteristic, thin and sterile, black layer (Cremonini and Farabegoli, 1977; Gasperi et al., 2005; Iaccarino and Papani, 1980) buried by the Pliocene clays.

A 4-km-long mud volcano belt (Bonini, 2012; Capozzi and Picotti, 2002) borders this sector of the Apennine front between Montegibbio and Nirano, comprising the most famous mud volcanoes of northern Italy (Martinelli et al., 2012; Martinelli and Judd, 2004). Here, the still-active chain hinge tectonics (Boccaletti et al., 2011; Picotti et al., 2009) gives rise to gas and oil seeps (Camerana and Galdi, 1911; Scicli, 1972), explaining place names such as Rio del Petrolio (Petroleum creek) and Sassuolo (Oil boulder), as well as historical seismicity reaching MCS scale IX (Guidoboni, 2010). In historical times between 1592 and 1835, the presently dormant Salsa di Montegibbio mud volcano, the largest in Italy (Figure $1 \mathrm{~b}$ and $\mathrm{c}$ ), displayed paroxysmal eruptions, with the expulsion of mud and boulders at times associated with recurrent seismic activity of low energy (Biasutti, 1907; Bonini, 2009; Govi, 1906; Stöhr, 1867). The related mud-volcanic deposits lie on an older morphological terrace at an elevation of approximately $275 \mathrm{~m}$ a.s.1. (Figure $1 \mathrm{~b}$ ), and their distal boundary reaches the Secchia River fluvial terrace at $170 \mathrm{~m}$ a.s.l. Until now, no chronological data have been available to date the onset of mudvolcanic activity; moreover, the volume of materials ejected during the last event in 1835 has been debated (Pantanelli, 1900).

\section{Methods}

\section{Archaeological and geoarchaeological surveys}

Archaeological deposits and structures were recovered according to modern scientific excavation rules (Barker, 1993) and by means of vertical sections cut down to the sterile natural soil wherever possible; all the recorded data were mapped using a total station (Figure 2), producing a contour-level map of the archaeological excavation and the surrounding topographic surface.

Each stratigraphic unit was described by texture, Munsell soil colour code, boundary geometry, inner characteristics and artefact contents. Artefacts were recovered and typologically studied and dated. Laser scanner surveys were also performed in Sector A to better record the archaeological structure planform and related deformations. Peculiar problems were encountered along the shear zones linked to the fault planes, where stratigraphic units appear vertical and stretched or elided in part. These unusual situations, not included in any category of the Harris Matrix system (Harris, 1989), were observed and carefully reported. Thin sections for micromorphological purposes were prepared from two samples recorded from the whitish loams of mud-volcanic mudflows and on the $\mathrm{B}$ and $\mathrm{B} / \mathrm{C}$ horizon of the reddish Alfisol buried in Sector B. The optical analysis was performed according to Stoops' suggestions (Stoops, 2003).

\section{Radiocarbon dating}

Radiocarbon dating carried out on charcoal fragments recovered from selected stratigraphic units (Table 1 in Supplementary materials, available online) was used to independently constrain the stratigraphic chronology derived from the classic ceramic typological method. Nine samples were taken from stratigraphic units that are particularly rich in organic remains, lying in the deepest reaches of Sector $\mathrm{B}$ of the excavation (Figure 3c). The dating was performed at the CEDAD (Centro DAtazione e Diagnostica) Laboratory of Salento University (Lecce, Italy) by AMS technique, based on international standards. The ${ }^{14} \mathrm{C}$ age calibration used OxCal ver. 3.10 (Reimer et al., 2013).

\section{Palaeo-archaeobotanical analyses}

Archaeobotanical analyses were performed on a set of six sediment samples for pollen analyses (2-9 g each) and six sediment samples for seed/fruit analyses (3-13 L each). Samples were collected from different archaeo-stratigraphic units covering a time frame from the prehistoric period to the beginning of the 5 th century AD. Among pollen samples, two more $(2 \mathrm{~g})$ were collected from the two whitish mud layers for palaeobotanical analyses.

Pollen samples. Samples were treated for pollen extraction according to the method of Florenzano et al. (2012). This method includes sieving and heavy liquid separation using tetra-Na-pyrophosphate, treatment with $10 \% \mathrm{HCl}$, acetolysis, and separation with Na-metatungstate hydrate, $40 \% \mathrm{HF}$ and ethanol. Lycopodium tablets were added to calculate pollen concentration (expressed as pollen grains per gram $=\mathrm{p} / \mathrm{g}$ ). Pollen samples were 

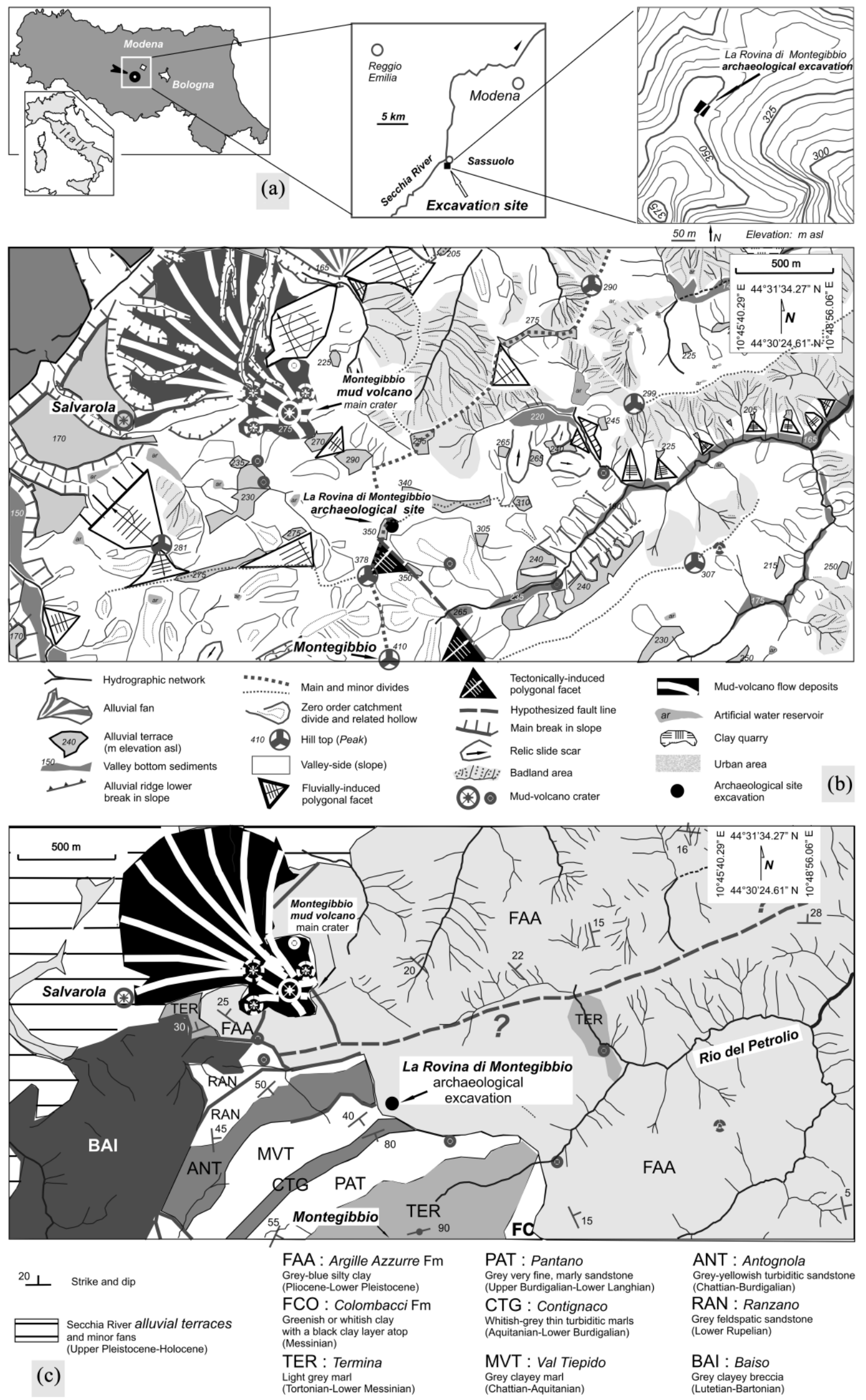

Figure I. (a) La Rovina di Montegibbio site location. The contour level lines were redrawn after Carta Tecnica Regionale of Regione EmiliaRomagna (Sheet 219080). (b) Geomorphological and (c) geological settings of the archaeological excavation site. The geological map was redrawn and partially revised after Gasperi et al. (2005). 

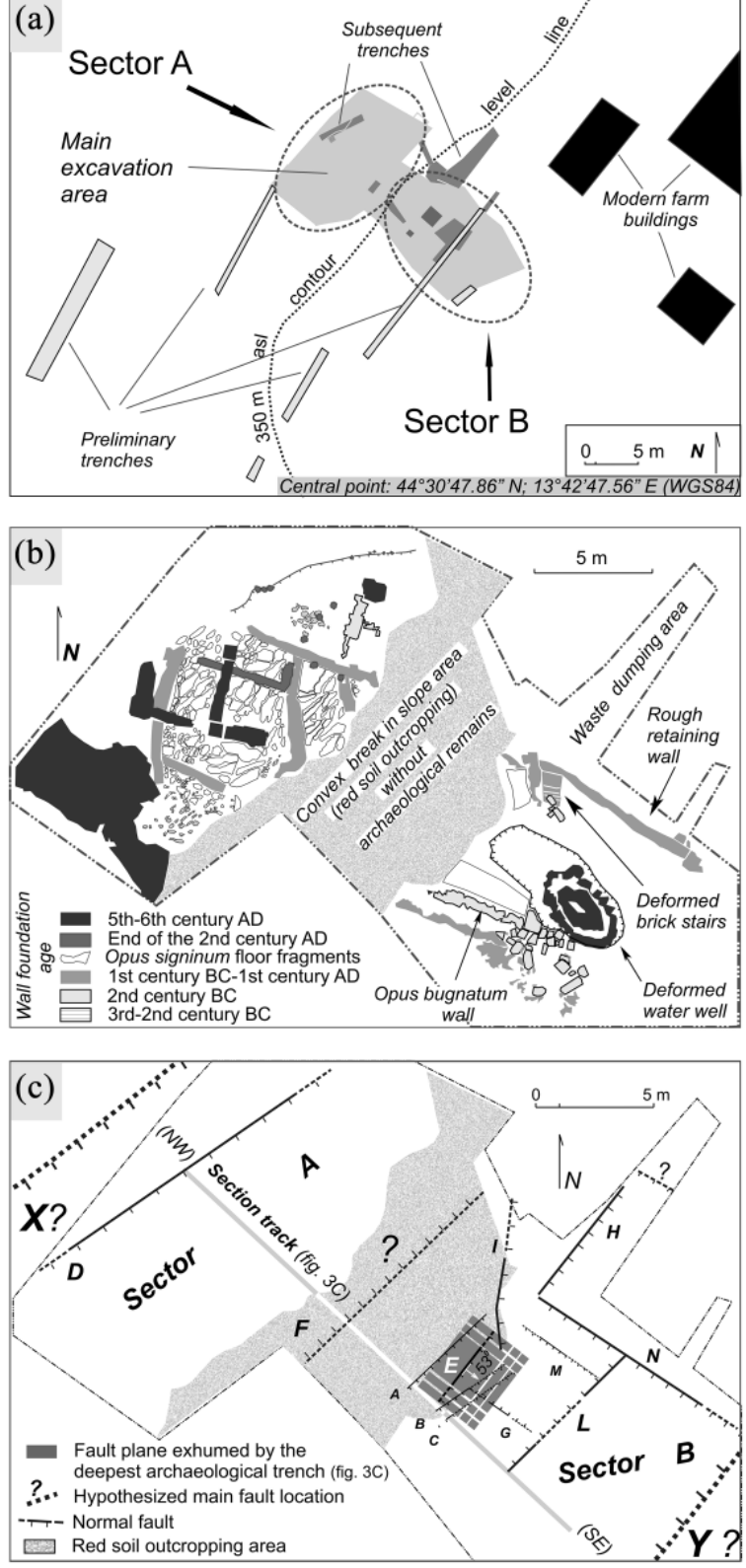

Figure 2. La Rovina di Montegibbio site excavation details. (a) Archaeological sectors and trenches location. (b) Main archaeological structures map. (c) Location of faults system recorded during the archaeological excavations.

mounted on slides with glycerol jelly. Identification was performed at $1000 \mathrm{X}$ magnification. The identification of archaeobotanical finds was performed with the help of a reference collection, atlases and keys. Pollen taxa nomenclature mainly followed Moore et al. (1991) and the Northwest European Pollen Flora (Punt and Clarke, [1980] 1981; Punt et al., 1976, 1995, (2003] 2009). The percentage pollen diagram was calculated on pollen sums including all pollen counted and was drawn with the software TGView (Grimm, 2004).

Seeds/fruits samples. Carpological samples were sifted in water (sieves of 10, 0.5 and $0.2 \mathrm{~mm}$ mesh size) based on methods currently in use (Pearsall, 2015). Seeds and fruits from each fraction were sorted and counted under a stereomicroscope. Identification was performed at $80 \mathrm{X}$ magnification. The identification in this case was also performed with the help of a reference collection, atlases and keys (e.g. Anderberg, 1994; Berggren, 1981; Cappers et al., 2006).

\section{Geochemical analyses of sediment and water}

The concentrations of boron and other major and minor elements were determined for all available soil and water samples, and $\delta^{11} \mathrm{~B}$ analyses were carried out on a selected significant number of samples (Tables 2A and B in Supplementary materials, available online). The available $\mathrm{B}$ in soil samples was extracted in a 1:2 (w/v) solid:10 $\mathrm{mM} \mathrm{CaCl}$ solution. The sample solution was shaken for $24 \mathrm{~h}$ at room temperature and filtered on Whatman ${ }^{\circledR}$ no. 42 (Kaplan et al., 1990). In the extract, the total content of B was measured by inductively coupled plasma optic emission spectroscopy (ICP-OES, Ametek, Germany) (Table 2A in Supplementary materials, available online). The analysis of $\mathrm{B}$ isotopes $\left({ }^{10,11} \mathrm{~B}\right)$ was carried out by ICP sector field mass spectrometry (ICP-SFMS). The water samples were filtered on Whatman no. 42 , and the total contents and isotopes of B were measured as described above.

The $\delta^{11} \mathrm{~B}(\%)$ analyses were performed by the ALS Scandinavia AB (Luleå, Sweden) Laboratories (Lab ID: U11046642U11046648). Samples were prepared by ionexchange pre-concentration. The analysis was carried out by ICP-SFMS (ELEMENT XR, ThermoScientific). Delta values were calculated to NIST SRM 951, and SD values were calculated from two independent consecutive measurements (Table 2B in Supplementary materials, available online).

\section{Geophysical surveys}

Four high-resolution seismic reflection sections (L0, L1, T1, and T2) were recorded over and around the archaeological excavation area (Figure 4). Two further high-resolution seismic reflection sections (S1 and S2) were performed in the area of the Salsa di Montegibbio mud volcano (Figure 5). A Vibroseis S-wave survey (L0) was performed using a Geometrics Geode seismograph equipped with 30 geophones $(10 \mathrm{~Hz}$ horizontal S-wave sensor) spaced $1 \mathrm{~m}$ apart. A record length of $11 \mathrm{~s}$ was selected with a sample interval of $0.25 \mathrm{~ms}$. The seismic source was an S-Waves Vibroseis Mod. Elvis III System 8 with a sweep length of $10 \mathrm{~s}$ and a sweep frequency of 20-160 Hz. The vibrating point interval was $1 \mathrm{~m}$, consecutively located at each geophone location from 1 to 30 .

The P-wave surveys L1, T1, T2, S1 and S2 were performed using a 72 CHS Geometrics Geode seismograph equipped with 72 geophones (10 Hz vertical $\mathrm{P}$-wave sensor), spaced $1 \mathrm{~m}$ apart for line $\mathrm{L} 1,1.5 \mathrm{~m}$ apart for line $\mathrm{T} 1$ and $0.5 \mathrm{~m}$ apart for line T2. The coverage in the centre of the section was $3600 \%$. A record length of $0.5 \mathrm{~s}$ was selected, with a sample interval of $0.25 \mathrm{~ms}$. The seismic sources were $8-\mathrm{kg}$ sledgehammer blows with shot points located at each geophone site for all three lines. The filters were set as out. The Moscow State University RadExPro QC configuration (2011.4b version, www.radexpro.com) was adopted as the processing software involving the following main processing steps: input data, geometry assignment, amplitude corrections, deconvolution, trace interpolation, filtering, velocity analysis (using the 'interactive analysis of stacking velocities' option), NMO correction, CDP stacking, time-depth conversion and F-K migration, which substantially improved the seismic imaging. Finally, data recorded along lines L1 and $\mathrm{T} 1$ were used for a seismic refraction tomography survey.

\section{Results}

\section{Archaeology}

The archaeological assay was performed in the upper Rio del Petrolio catchment (Figure 1), whose left lateral branch was still named Rio dei Bagni (Baths Creek) at the beginning of the 20th century (Camerana and Galdi, 1911). The excavation was split into two sectors (Figure 2) lying at $351 \mathrm{~m}$ a.s.l. (Sector A) and 348 $\mathrm{m}$ a.s.l. (Sector B). 
(a)
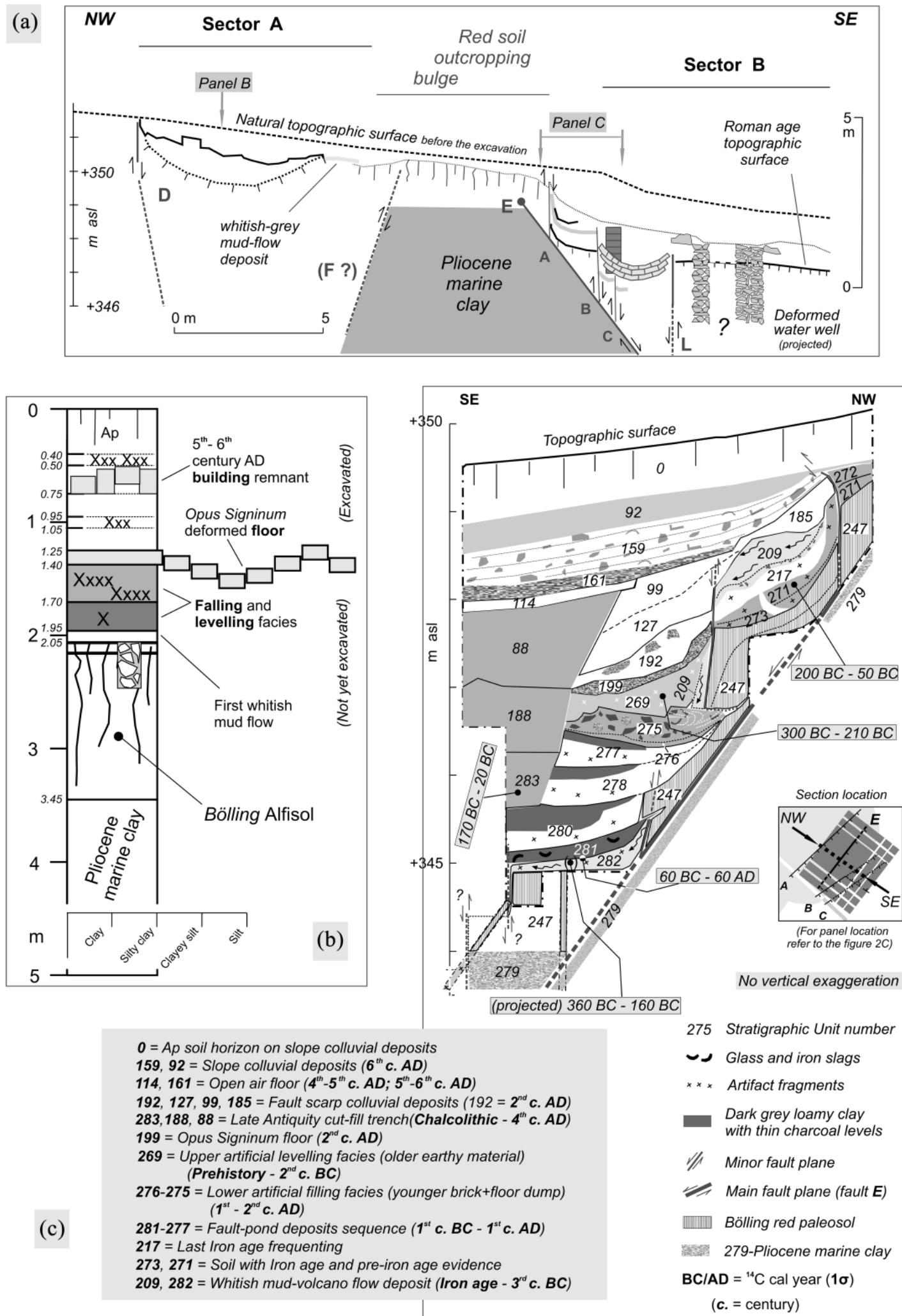

Figure 3. (a) Simplified geological section across the excavated area. The section location is shown in Figure 2c. (b) Schematic line draw of the Sector A stratigraphy. (c) Detailed stratigraphic section recorded in the core of Sector B (southern wall of the central pit-trench). The labelled stratigraphic units (US) are dated according to the archaeological findings chronotypology.

The site history can be summarized according to the following essential outline (Figure $2 b$ ):

- In the 3rd century BC, frequenting of the site area is already recorded.
- In the 2nd century BC, a low stony enclosure-like wall of sacred character was built around a water spring occupying a small pond in the slope, together with other rooms, now poorly preserved. The whole building is considered a sanctuary dedicated to the Minerva Medica, according to 


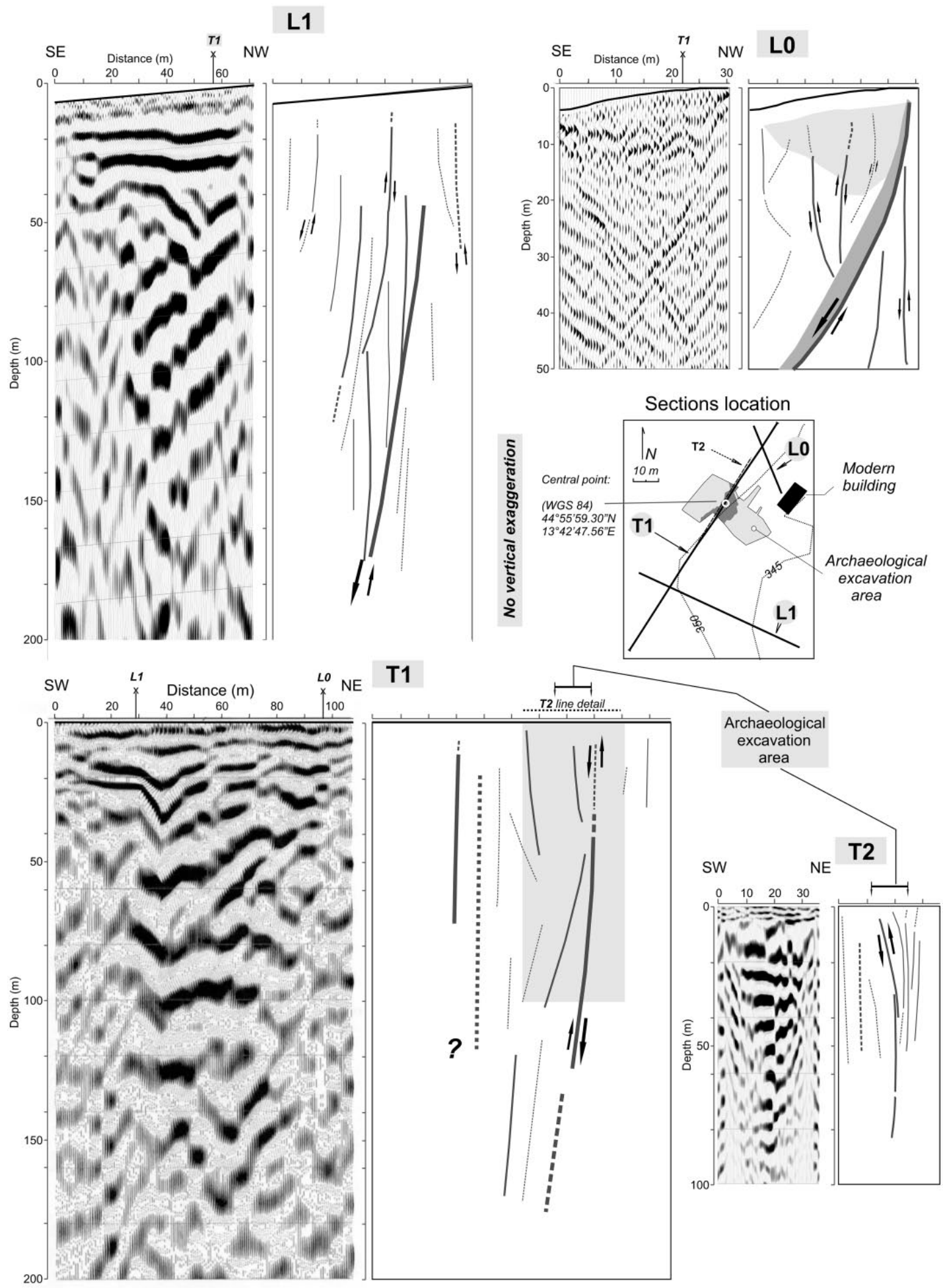

Figure 4. Seismic sections LI,TI,T2 and L0 carried out in the archaeological site area. For each section, depth/distance stacks (left side) and related interpretation (right side) are shown. The related stacks time/CDP and $V_{p}$ are reported in Figure 2 of the Supplementary materials, available online.

a distinctive masonry technique (Opus bugnatum, i.e. squared sandstone blocks). This technique is quite different from the usual unbaked earthen materials, highlighting the importance of the building itself. The alleged healing properties of the spring waters are supported by a very large number of sherds pertaining to drinking cups (vasi potori), showing the etched name of the goddess (Figure 1 in Supplementary materials, available online).

- In the 1 st century $\mathrm{BC}$ and up to the 1 st century $\mathrm{AD}$, after the destruction of the sacred enclosure testified by the deformation of the walls, the levelling of old ruins and the construction of a new building took place. The new building was characterized by a refined floor in Opus signinum (a mosaic-decorated concrete); in the northern sector, a retaining wall was also built to protect the still-preserved hollow beside the sacred spring, and a brick stair was added to enter it.

- At the end of the 1 st century $\mathrm{AD}$ or the beginning of the 2nd century $\mathrm{AD}$, the building was destroyed by severe hillslope deformation.

- During the 2 nd century AD, the site was abandoned. 

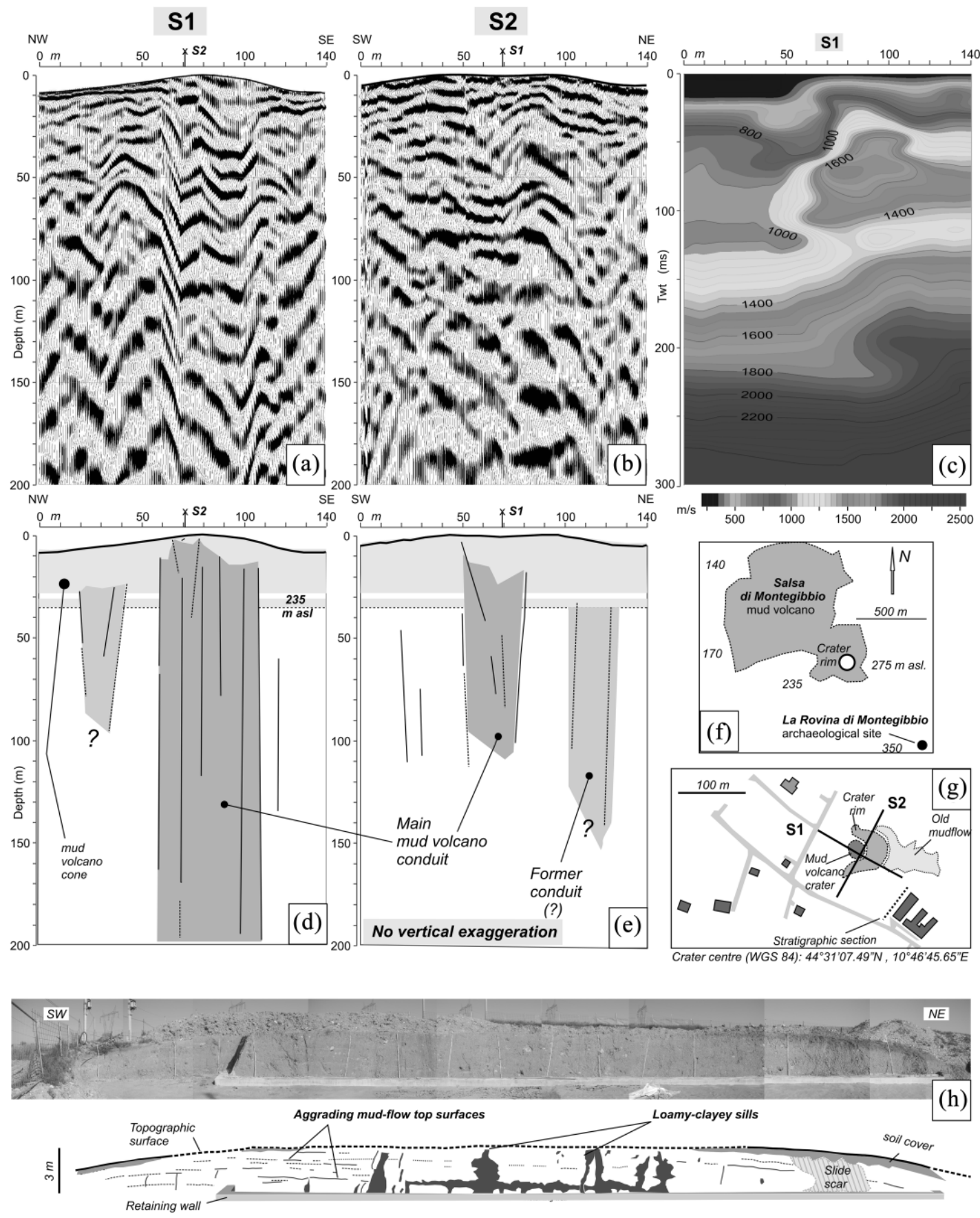

Figure 5. Crossed seismic sections and stratigraphic section recorded across the summit area of the Salsa di Montegibbio mud volcano. (a) Depth/distance stack of the seismic section SI. (b) Depth/distance stack of the seismic section S2. (c) Stacks TWT/distance and Vp of the seismic sections SI. (d) Interpretation of the seismic section SI: the dotted line (+235 m a.s.l.) shows the morpho-stratigraphic boundary highlighting the possible base of the mud-volcanic building (e.g. Higgins and Saunders, 1974). (e) Interpretation of the seismic section SI. (f) Mutual location of the Salsa di Montegibbio mud volcano and La Rovina di Montegibbio archaeological site (see also Figure I (b)): the white circle represents the summit area around the volcanic crater. $(\mathrm{g})$ Detailed location of the seismic lines SI and S2. (h) A shallow, tangential stratigraphic section of the south-eastern reach of the external crater rim recorded on 29 May 20 I2: location in (g).

- At the end of the 2nd century AD, a small farm was built.

- In the 4th century AD, a water well was excavated on the plumbline of the old, buried sacred spring. The well was then distorted by ongoing deformation.

- In the 5th-6th centuries AD, another farm was built. Even this building was progressively deformed.

In the Emilia region, the walls of ancient archaeological structures were usually built with loamy clay materials and plastered, using backed bricks only for foundations. For this reason, no vertical remains of walls were found, except for the cases of the Opus bugnatum enclosure and of a thick retaining wall.

\section{Geology}

Almost all the recorded deposits can be described as loam or loamy clay, resulting from natural or artificial reworking of the blue-grey-coloured Pliocene marine sediments. The Sector A depositional sequence is relatively simple, whereas the Sector B sequence has been quite disturbed by severe post-depositional processes.

In Sector A, approximately $80 \mathrm{~cm}$ of anthropogenic sequence (Figure $3 \mathrm{~b}$ ) covers the reddish natural soil up to the main mosaic floor (Opus signinum), and upon this, a 1-m-thick sequence of materials from wall degradation and resettlement phases is recognized. Sector B, in contrast, records a complex set of small, different 
stratigraphic themes, varying from point to point, with both a 3-m-thick facies of colluvial deposits and a waste dumping facies discharged in a marginal area.

In the excavation, three layers are found and used as guide horizons for correlations between Sectors A and B: (1) the yellowish-red Bt horizon of the Bölling palaeosol resting upon the Pliocene blue-grey clays and (2) two whitish-grey silty-clay layers. The latter display a whitish-grey colour, quite different from the Pliocene blue-grey marine clays, with thicknesses ranging from 20 to $40 \mathrm{~cm}$ each, an undisturbed massive structure, and no slickensides, together with intact microfossils and a peculiar palynological content. The first whitish mud layer rests upon the former A horizon of the reddish palaeosol and is widespread all across the archaeological site area. This layer shows evidence of Iron Age frequentation and sustains all Roman-age building structures. In detail, it is composed of two distinct layers, divided in places by a number of decimetre to centimetre-sized fragments of whitish marls. Each sub-layer records weak evidence of trampling/frequenting consisting of a few, very small charcoal and baked-earth fragments. The second whitish mud layer was deposited later (2nd century AD) in only the northern part of Sector B. This layer does not cap any structure of Sector A and thickens from NNW to SE. In this mud layer, a high concentration of black earthen material is found, showing centimetre to decimetre sizes and slightly rounded edges. The relics are organized along planes parallel to the base of the mud layer. Overall, the white mud matrix displays a fluid flow-like structure, coating walls and objects and filling the major voids.

In the 5-m-wide string, that is, a NE-trending small-scale horst separating Sectors A and B, the reddish Bölling palaeosol crops out, and the archaeological structures are completely lacking. Erosion has affected the top of the horst structure, causing the archaeological structures to disappear. In fact, the sacred spring in Sector B probably disappeared during the abandonment phase between the 2 nd and the $3 \mathrm{rd}$ centuries $\mathrm{AD}$, covered by the fine slope deposits generated by the central horst degradation. During the 4th century $\mathrm{AD}$, a memory of the existence of the ancient spring was preserved by the construction of a large-diameter water well along the former depression plumbline. This sacred spring, then holy well, was successively replaced until the Renaissance period by two other water springs located tens of metres downslope, which are currently partly preserved.

In Sector B, four thin soils, ranging from Colluvic Regosol to Garbic/Urbic Technosols (FAO, 2014) linked to the frequentation of the site throughout time, are preserved. In particular, the latest one, dating back to the 4th-6th centuries AD, almost simulates a Dark-Earth deposit (Goldberg and Macphail, 2006). Very slow soil creep and agricultural activity contributed to reshaping the slope, almost dismantling natural scarps and hollows. The most astonishing character of the La Rovina di Montegibbio archaeological site is the set of deformations affecting geological deposits and archaeological structures.

The excavation site records at least four types of deformations (Figure 3). Local subsidence occurred in the middle of the excavation site (Sector B) and produced a depression involving the most ancient outer walls of the sanctuary (Figure 6a). The most ancient archaeological remains are found near the bottom of this subsiding area (Figure 3c). Wavy deformations, with bulges and depressions (Figure 2 in Supplementary materials, available online), affected the mosaic floor of the early imperial Roman age, located in Sector A. Two main orthogonal systems of faults cut the buried archaeological layers throughout the whole area, showing a double staircase feature with up to a 5-m drop of the ancient topographic surface (Figure 3a). Further vertical deformations affected the retaining wall located in Sector B. In Sector A, at least two groups of orthogonal shear zones are recognized to intersect the Roman-age remains and the underlying Alfisol
(Figure 2c). One of them, with an inclination of $53^{\circ}$ (Figure 6c and d), coupled with a set of minor synthetic faults (Figures $3 \mathrm{c}$ and $6 \mathrm{~b}$ ), is observed to have lowered the ancient ground surface in Sector B by at least $4 \mathrm{~m}$ and to continue for at least $2 \mathrm{~m}$ more into the hill core (Figure $3 \mathrm{c}$ ). All along the main fault plane, a 10-20-cm-thick chaotic, homogeneous silty material mainly originating from the dragging and packing of the reddish palaeosol along the shear zone is always present (Figures 3c and 6d, US 247). Similar features characterize the minor fault planes linked to the main fault plane. This set of deformations resembles that recognized in the Fucino area by Galli et al. (2012, Figure 11).

Another system of faults, striking orthogonally to the previous set and dipping to the $\mathrm{S}$, affects the oldest archaeological structures. Because of these two shear-zone sets, resembling a box-like system (Bertolini and Sartini, 2001), the central sector of the sacred area records the maximum subsidence (Figures $2 \mathrm{c}$ and $3 \mathrm{a}$ and $\mathrm{c})$.

\section{Radiocarbon ages}

The ${ }^{14} \mathrm{C}$ ages are listed in Table 1 (in Supplementary materials, available online). Some of them refer to samples from stratigraphic units in the core of the Sector B depression. Dates and their stratigraphic locations are shown in Figure 3c. Their results are fully consistent with the stratigraphic superposition principle if the reworking processes are considered. For example, stratigraphic unit US 275 refers to the first crumbling/levelling facies located on the former spring-pond sequence and is the base of the Opus signinum floor. The overlying stratigraphic units were generated by colluvial processes; hence, they contain more ancient materials with respect to the age of deposition. The same can be said for the US set $88+188+283$ filling up the trench for construction of the late antique water well.

\section{Pollen and seeds/fruits in archaeological sediments}

In this study, the pollen content of a few selected samples from whitish mudflow deposits and related inclusions was analysed, and new archaeological samples were added to the research and incorporated with the results of previously published samples (Montecchi and Accorsi, 2010). Pollen is found in all samples, except in the black earthen relics included in one of the whitish mudflow layers. The state of preservation is various, from mediocre to discrete, but on the whole, the preservation allows reliable analyses. A number of grains are broken, and some pieces of exine are not identifiable. Deteriorated pollen is mainly transparent or crumpled/folded, as an effect of trampling or the presence of oxygen-rich surfaces, as commonly observed in archaeological samples. The data prove, in addition to synanthropic plants, the presence of wetland plants at the time of the sanctuary (Figure 3 in Supplementary materials, available online). At the same levels, a few charred seeds/fruits testify to possible plant offerings: figs, walnuts, grapes, cereals and pulses (Rinaldi et al., 2010).

\section{Pollen in whitish mud layers}

In the whitish matrix, pollen grains of tree taxa currently extinct in the area, such as Tsuga and Cathaya, have been found mixed with younger grains that probably do not predate the Neolithic or even the Bronze Age, since pollen grains of cultivated cereals are identified, as evidence of agricultural activities. The fact that Tsuga and Cathaya were widespread during the Tertiary (Ekenwalder, 2009; Taylor et al., 2009) until their disappearance in Italy approximately $800 \mathrm{ka} \mathrm{BP}$ (Bertini, 2010), together with the absence to date of grains belonging to Taxodiaceae, confirms that the mud deposits originated from Tertiary formations that do not crop out near the archaeological site at present and are buried at 

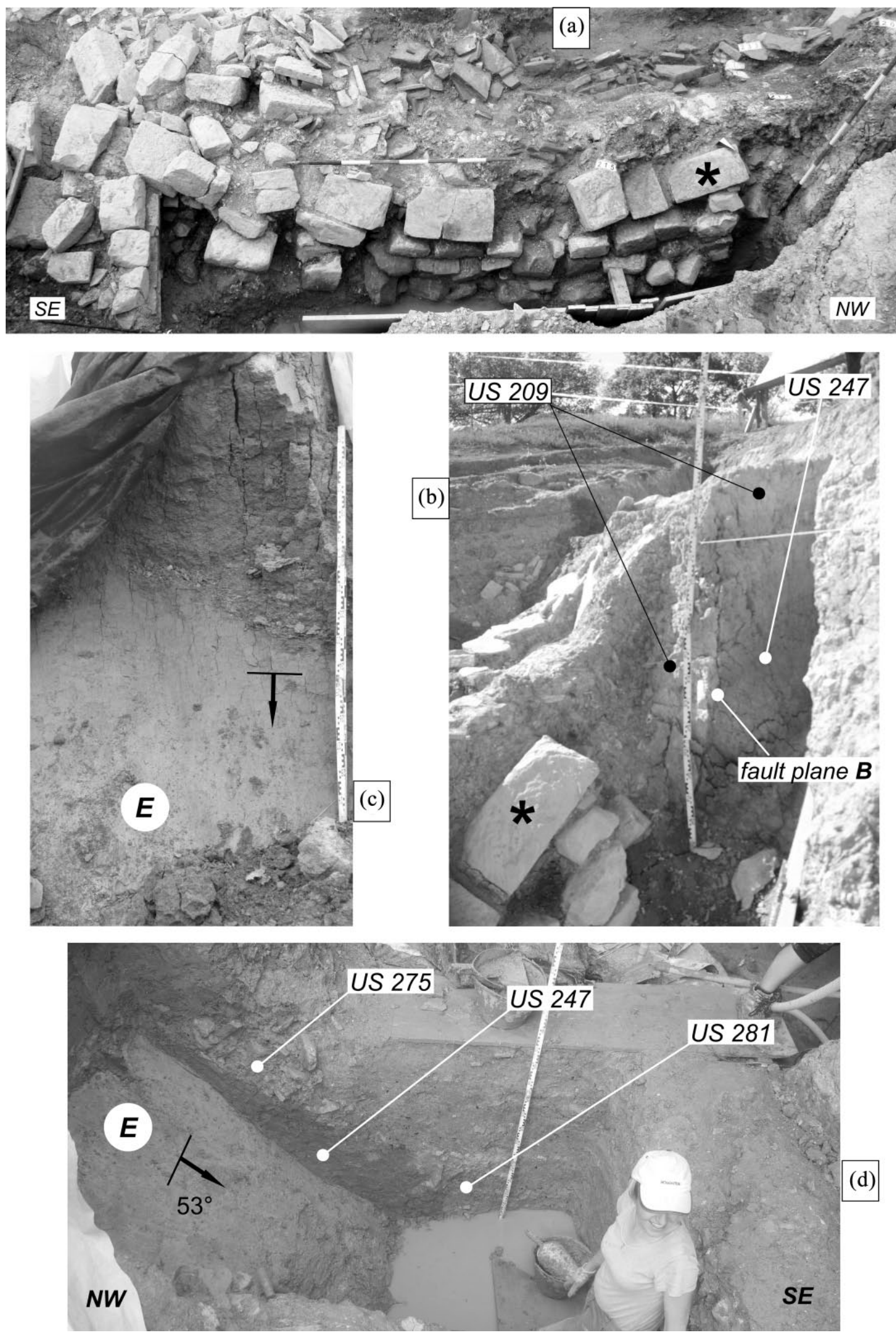

Figure 6. (a) The deformed Opus Bugnatum wall. The fault plane B lies on the right of the photograph. The black star identifies the same block of (b). (b) Section of the minor fault plane B marked by a vertical contact between the yellowish-red palaeosol and the first whitish mud behind the levelling rod. The levelling rod marks are in centimetres. The black star identifies the same block of (a). (c) The upper termination of the fault plane E cleaned in excavation Sector B. The levelling rod has a centimetre unit scale. (d) Picture of the central pit-trench northern wall. On the left side, the exhumed fault-scarp (e) can be observed. The levelling rod has a centimetre unit scale.

depth. This situation allows us to interpret this peculiar material as part of the buried. Colombacci Formation top (Cremonini and Farabegoli, 1977; Iaccarino and Papani, 1980). In contrast, the black earthen relics included in the most recent mud flow, as mentioned above, are sterile.

\section{Geophysics}

The investigated surface was $100 \times 80 \mathrm{~m}^{2}$, whereas the archaeological excavation area was approximately $30 \times 15 \mathrm{~m}^{2}$. The high-resolution active seismic surveys reached a depth of $200 \mathrm{~m}$ (Figure 4). In section L1, underneath a 20-m-thick, slightly deformed 


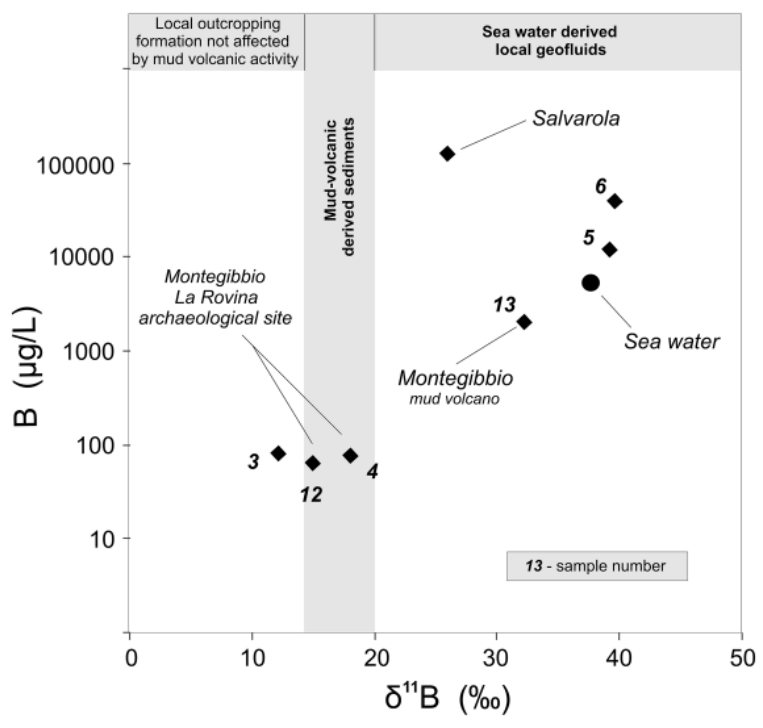

Figure 7. Elemental boron and isotope concentration of samples from selected sites. Mean seawater composition after Vengosh and Spivack (2000).

reflector set of Pliocene marine sediments, the surveys show a 20- to 40-m-wide set of high-angle listric faults, striking SSW-NNE, dipping to the ESE, and tending to fade under the nearby Rio del Petrolio talweg. The slightly different fault dips in the L1 and L0 sections depend on the different orientations of the sections themselves. The T1 section intersects this set of faults almost parallel to the shear plane direction, resulting in a sub-vertical aspect. Section T2 is a very high-resolution detail of $\mathrm{T} 1$ and displays consistent data. The archaeological site is located exactly in the area affected by this deformation (Figure 4: Line T2). The relative motion of the fault limbs (see the arrows) agrees with the stratigraphic and structural data recorded during the archaeological excavation.

As a pertinent comparison, the most relevant features of the fault system of the Salsa di Montegibbio mud-volcanic conduit are shown in Figure 5 and the related Figure 4 in the Supplementary materials, available online. Line $\mathrm{S} 1$ shows the whole diameter of the conduit (approximately 30-40 m) down to a depth of approximately $200 \mathrm{~m}$. S2 is almost tangent to the conduit, showing a less clear geometrical pattern and most likely part of former conduit scars. Neither S1 nor S2 is able to reach the mud chamber top, whose shape could be similar to that of Moruga mud volcano (Deville et al., 2003), although smaller. The sub-vertical faults limiting the mud-volcanic conduit can to some extent recall those recorded in other mud volcanoes (Somoza et al., 2012). Figure 5h displays a stratigraphic section recorded east of the mud volcano rim showing the mud layers and the clayey silts pattern.

\section{Geochemistry}

Representative samples of local geological formations cropping out in the excavation surroundings and archaeological layers as well as samples of deep-origin geofluids (Boschetti et al., 2015) were collected and analysed (Table 2A and B in Supplementary materials, available online). Water samples show a marked ancient marine geochemical signature, highlighted by $\mathrm{Cl}, \mathrm{Na}, \mathrm{K}$, $\mathrm{Li}$ and B concentration values (e.g. Serra, 1986). Boron isotopes have been considered potential tracers of geologically recent marine effects (Barth, 1993; Deyhle et al., 2003). Boron isotope values of the considered geofluids are within the range of brines (e.g. Barth, 1993). All rock samples show total B concentrations within the range of 40-6630 micro g/ $\mathrm{kg}$. Sediment samples from the youngest marine-environment units have a chemical composition significantly similar to that of the parental geofluids sampled in the nearest small brackish water springs. Sample 3 (Table 2 in Supplementary materials, available online) shows total B concentration values relatively lower than those of other rock samples, while the ${ }^{11} \mathrm{~B} /{ }^{10} \mathrm{~B}$ ratio is among the lowest of the considered data set. In particular, slightly higher ${ }^{11} \mathrm{~B} /{ }^{10} \mathrm{~B}$ ratios are measured in the muds interlayered with the archaeological setting (samples 4 and 12 in Figure 7). These samples could be relics of possible mudvolcanic activity related to ancient eruptive events. Sample 13 (Figure 7) represents the clayey phase of fluids extruded in relatively recent times (eruption of 1835 ), and the ${ }^{11} \mathrm{~B} /{ }^{10} \mathrm{~B}$ ratio is the highest among the considered sediments. The isotopic values of sample 13 are similar to the values found by Deyhle et al. (2003) and Pennisi et al. (2013b). Samples 4 and 12 could be representative of clayey sediments extruded by mud-volcanic activity during historical times. The ${ }^{11} \mathrm{~B} / 10 \mathrm{~B}$ values of samples 4 and 12 are lower than those of sample 13 and could be tentatively attributed to weathering processes (Stumm and Morgan, 1996).

\section{Discussion}

In European and Mediterranean areas, stone was used as building material, particularly in urban sites, throughout the past three millennia. In contrast, in northern Italy, where silty and clayey materials are available from alluvial plain deposits and rock masses cropping out in mountainous areas, the use of earthen materials was the rule up to the medieval period. This situation is particularly true in the Emilia region. Here, the lack of preserved ancient walls in archaeological contexts is a common fact because of both natural degradation processes of poor building materials and reuse stripping practices. Therefore, the cause of the collapse of a building can be interpreted with difficulty. In this case, only the analysis of ground deformations and related archaeological contexts can help (Curina and Cremonini, 2010). In the case of the Montegibbio-La Rovina site, the interactions among the archaeological structures and the ground deformations are quite strong.

The evidence of severe deformations and the set of field and analytical data suggest that geological forcing, that is, tectonics and the related mud-volcanic activity, could have been responsible for the onset, destruction and abandonment of the Roman-age settlement of La Rovina di Montegibbio.

People probably lived in the surroundings of this site since the Chalcolithic period, as testified by some sporadic archaeological findings hosted in the most ancient stratigraphic units found in the excavation. According to this finding, the archaeopalynological sample collected in these layers provides evidence for an open landscape, with a percentage of deforestation amounting to $47 \%$ (mainly represented by Quercus caducifolia, Alnus, Abies and Pinus) and synanthropic plants (5\%, i.e. Centaurea, Plantago, Urtica). No evidence has been recorded to support an already existing link between human settlement and peculiar geological phenomena during this period, with the unique attractive landscape featuring the existence of relatively large and flat morphological terrace suitable for settlement and related activities. It can be assumed that at the end of the Iron Age, that is, the beginning of the Roman-age colonization of the region, a small mud volcano and/or a salsa (water-dominated pool with gas seeps) or a spring (water-dominated outlet smaller than $0.5 \mathrm{~m}$ ) already existed and was able to catch the attention of the local people. Afterwards, at the inception of the Roman age, the site frequentation shows clear worship characteristics linked to the local natural fluid emissions, which were considered a gift from the underworld and related divinities. At the time of the sanctuary, a spring possibly hosted in the core of the sacred building (Figures 2 and 3: Sector B) was recognized to exist, as testified by the drinking cups (Figure 1 in Supplementary materials, available online) and by the percentage of humid environment plants $(6.5 \%)$ represented in pollen spectra (Figure 3 in Supplementary materials, available online). 
A contemporaneous plant-offering practice is also suggested by charred seeds/fruits (Rinaldi et al., 2010). From the hydrogeological point of view, the site is located on a catchment divide carved in clay-rich geologic material, where no freshwater springs can be found. In fact, even today, local farmers have to build small surficial water reservoirs or drill deep wells because of the scarcity of the water supply along the hillslopes. The small water pool could have developed as a sag pond in an active tectonic setting, but the ground deformations appeared only later and more likely led to the progressive deactivation of groundwater flow. All these elements suggest that the water uprising was linked to deep groundwater circulation connected with a larger mud volcano system. In addition, some subsequent natural deposits suggest that the same kind of environment existed. The two whitish mud layers, in fact, may be interpreted as emission products of a previously unknown, small-scale mud volcano, whose conduit was probably located very close to the excavation area, upslope from its northern side. This idea is mainly supported by the deposit thickening trend that rapidly develops towards the NW, particularly in the case of the second flow. The pollen grains of tree taxa currently extinct in the area identified in samples from these layers demonstrate that the whitish muds came from Tertiary geological units buried at depths from 100 to $800 \mathrm{~m}$. In fact, in a mine pit cored very close to the archaeological site in the 19th century (Camerana et al., 1926), beneath 12-m-thick Pliocene blue-grey clays, whitish marls were found down to $670 \mathrm{~m}$ depth. Moreover, the local tectonic setting suggests a sub-vertical attitude of geological units (e.g. Contignaco and Termina), allowing for fast fluid ascent and homogeneous composition of the white muds. A further proof corroborating this interpretation is the presence of a considerable number of large (centimetre to decimetre-sized) fragments of black earthen materials 'mud breccias' pertaining to the top of the Colombacci Formation intermingled with the whitish matrix of the second mudflow. The mud-volcanic origin of these layers is also confirmed by geochemical analyses, consistent with other geochemical data sets (Martinelli et al., 2014; Vengosh and Spivack, 2000).

The ground deformations affecting the area were scattered through time (Figure 8). The first deformation event and the consequent rebuilding phase occurred at the beginning of the 1st century $\mathrm{BC}$. At the beginning of the 2 nd century $\mathrm{AD}$, a severe ground deformation phase occurred, and the sanctuary and the site itself were abandoned (Guandalini, 2009). A century later, three phases of rural settlement followed, dating from the 3rd to the 6th centuries AD. During this last period, and probably later as well, the deformations continued to develop, characterized by only vertical displacements. The deformations severely changed the original flat terrace morphology, generating an escarpment corresponding to the downslope side of the central horst-like structure dividing the excavation Sectors A and B. Atop this earthen pillar, erosion dismantled all evidence of the archaeological structures down to the Bt red horizon of the natural Alfisol. This structure corresponds both to a preserved surficial, smoothed micro-ridge less than $0.5 \mathrm{~m}$ high, still visible on the ground, and to the shallowest fault planes recorded in sections L1 and T2. In particular, the structure corresponds to the Pliocene unit deformation located at a $45 \mathrm{~m}$ distance in section L1. This evidence could indicate a sort of active/quiescent buried structure motion.

The pattern of outcropping geological structures fits with the fault set recorded by high-resolution active seismic surveys (Figure 4). A comparison between the 3D pattern of faults in Figures 4 and 5 highlights some differences. For this reason, it is thought that the whitish mud eruptions could have resulted from the functioning of a relatively small and distal system of mutually interplaying faults rather than a large mud volcano. These faults may represent preexisting tectonic structures that might have been reactivated during fault-controlled eruptive events (Bonini, 2012). In 91 BC, a Me 5.6 seismic event was recorded in the Po plain (Guidoboni et al., 2007).
The event was followed by an intense eruptive phenomenon at the Montegibbio mud volcano observed from a long distance (see also Bonaposta and de Nardo, 2017; Casoli, 2001). The effect of earthquakes on the activity of mud volcanoes has been recorded in other similar cases, also when the epicentral area was located at some tens of kilometres (Bonini, 2009; Bonini et al., 2016; Manga et al., 2009; Mellors et al., 2007). It should be noted that mud-volcanic activity can be particularly intense and dangerous (Bonini et al., 2016 and references therein). The whole set of observed deformations recorded at La Rovina di Montegibbio could, in principle, be generated by seismic activity and/or mass movements along the hillslope, but the observed brittle and plastic deformations cannot be correlated with seismic events for three reasons. The first reason is that the deformations are multiple and span several centuries. The second reason is that none of the observed deformation can be regarded as synchronous with the year $91 \mathrm{BC}$ seismic event and that one from the beginning of the 1st century $\mathrm{BC}$ is characterized by a very small size when compared with the following deformative phases, which occurred approximately two centuries later (Figure 8). Finally, no diffuse destruction (Galadini et al., 2006; Guidoboni and Ebel, 2009; Stiros and Jones, 1996) is recorded at that time throughout the landscape surrounding Montegibbio. As far as slope processes are concerned, the displacement vectors and their main vertical components clearly demonstrate that the movements cannot be referred to as gravitational-driven processes (see, for instance, $\mathrm{Xu}$ et al., 2018); in fact, there is no evidence of archaeological structures sliding downslope. Furthermore, it should be noted that while the detected fault planes reach a depth of at least $200 \mathrm{~m}$, the thickness of landslide bodies in the northern Apennines is usually not larger than a few tens of metres (Bertolini et al., 2005), except for a few cases such as the Corniglio landslide, where the depth of the sliding surface is of the order of 100 $\mathrm{m}$ (Larini et al., 2001). Thus, the observed severe deformations and related damage can probably be referred to an active mud-volcanic environment as well as the related tectonic setting.

Present-day mud volcano activity and related surficial damage can be considered valid comparisons in order to disentangle our evidence. Fluid expulsion phenomena have been documented to cause severe ground deformations because of fluid pressure and volume variations in the reservoir (Guliyev and Huseynov, 2015; Higgins and Saunders, 1974; Kopf, 2008). Uplift/subsidence patterns and brittle fracturing/faulting related to mud-volcanic eruptions have recently been identified using InSAR techniques (Antonielli et al., 2015). Damage to buildings (Figure 5 in Supplementary materials, available online) has been observed close to mud-volcanic craters located in the Marche and Sicily regions (Costa et al., 2008; Damiani, 1964; Madonia et al., 2011). The area affected by deformations is approximately $500 \mathrm{~m}$ wide (Figure 9e and $\mathrm{f}$ ), and deformation trends do not coincide with the main local geological structures. Cracks and subsidence on slopes have been observed in the vicinity of the Puianello mud volcano (Mulas et al., 2016), located $10 \mathrm{~km}$ ESE of Montegibbio (Figure 9d). Therefore, the area that can be affected by deformations is generally larger than the dimension of the mud reservoir's uppermost level, recognized, for example, in the Nirano mud volcano area (60 $\mathrm{m}$ according to Accaino et al., 2007). Thus, we can infer that the area affected by deformations driven by the Salsa di Montegibbio mud volcano system can reach the La Rovina di Montegibbio slope and the archaeological site.

A further piece of evidence concerns the variability of mudvolcanic activity. In the Montegibbio area, brackish groundwater has been exploited since Roman times (Doderlein, 1867) and is still used today in the Salvarola Bath Spa, $2 \mathrm{~km}$ from the archaeological excavation site, although Casoli (2001) reports a possible decrease in eruptive activity of the Montegibbio mud volcano because of the exploitation of the Salvarola brackish groundwaters. In November 2008, an aseismic eruptive phenomenon affected the Salvarola area, and several thousand litres of mud 

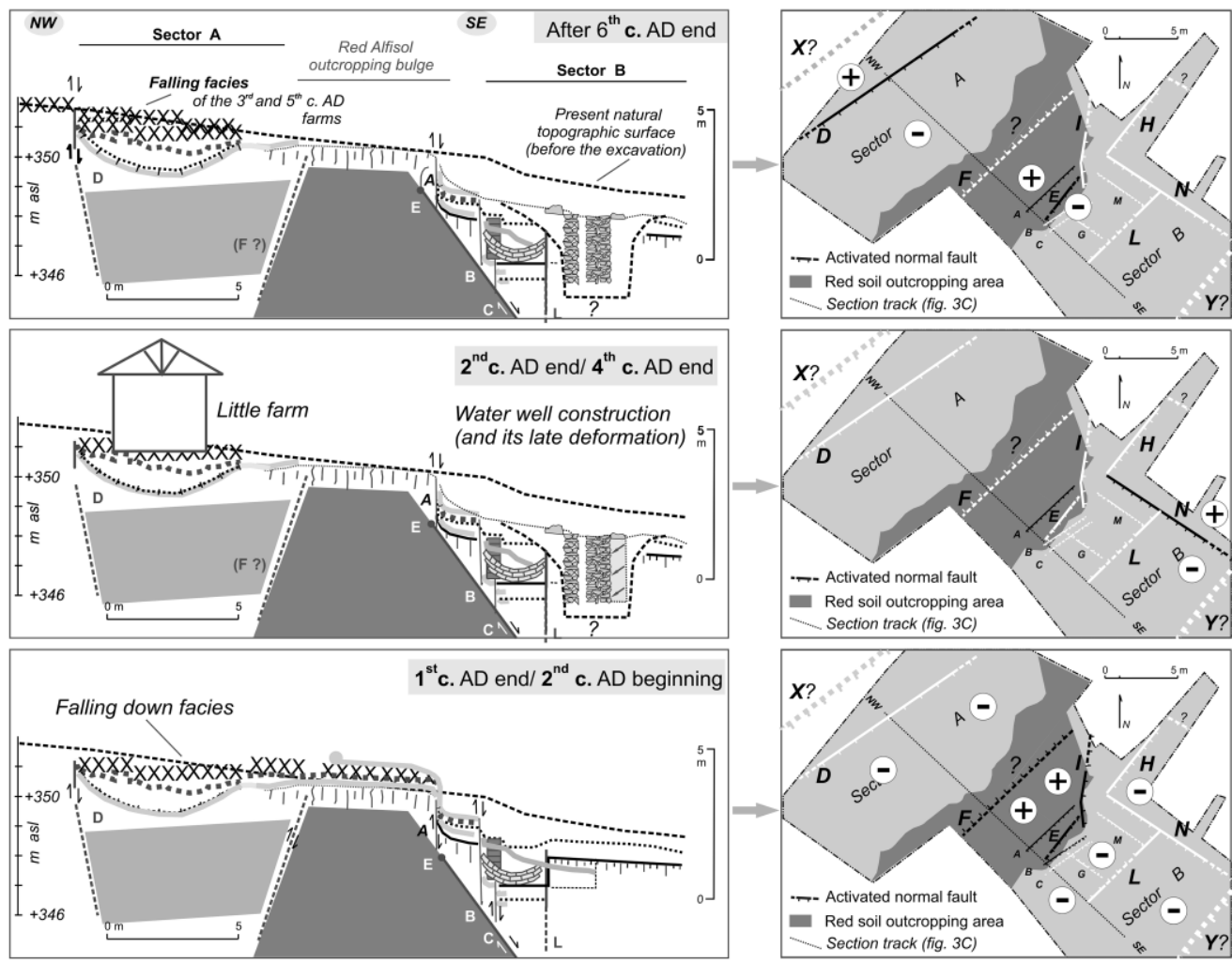

(e)
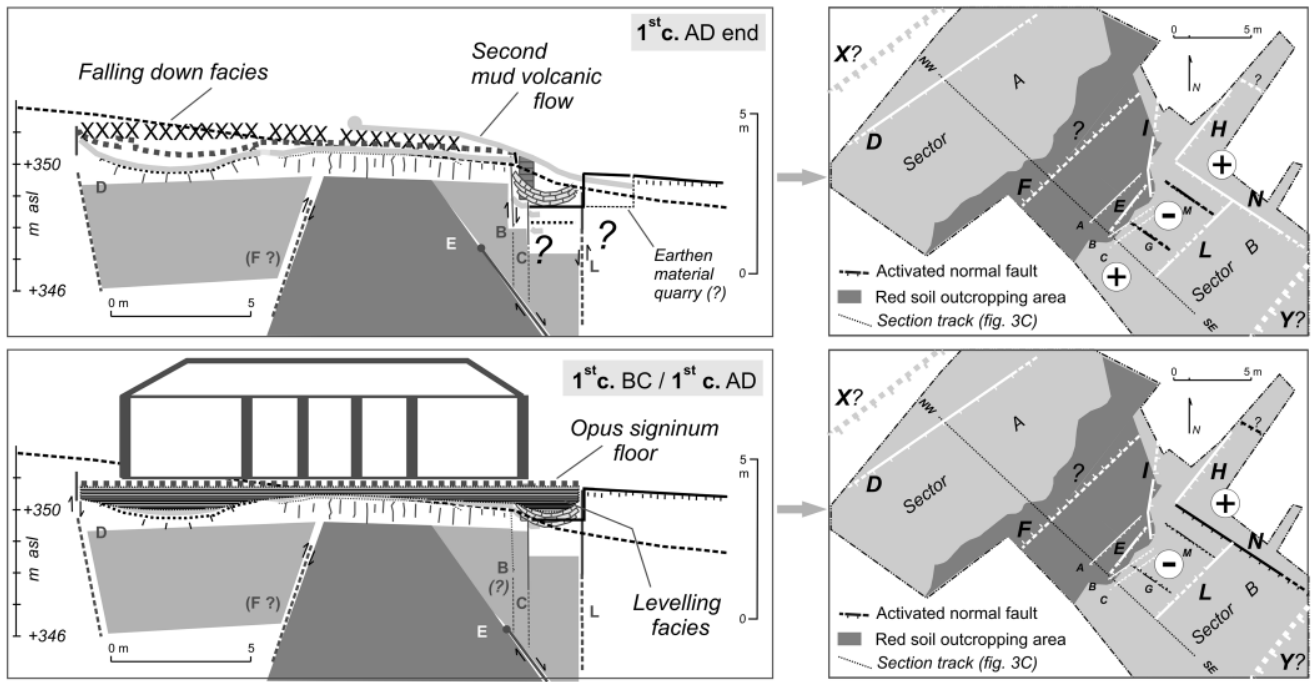

(d)
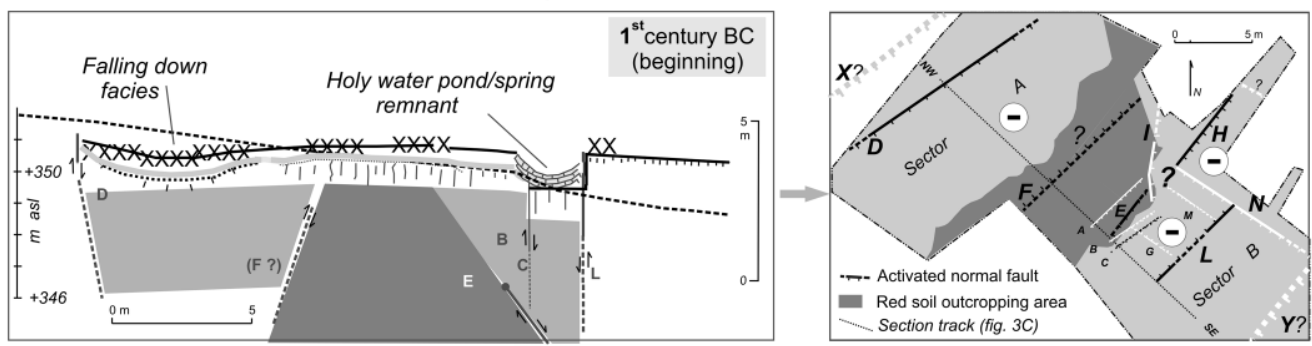

\section{(c)}
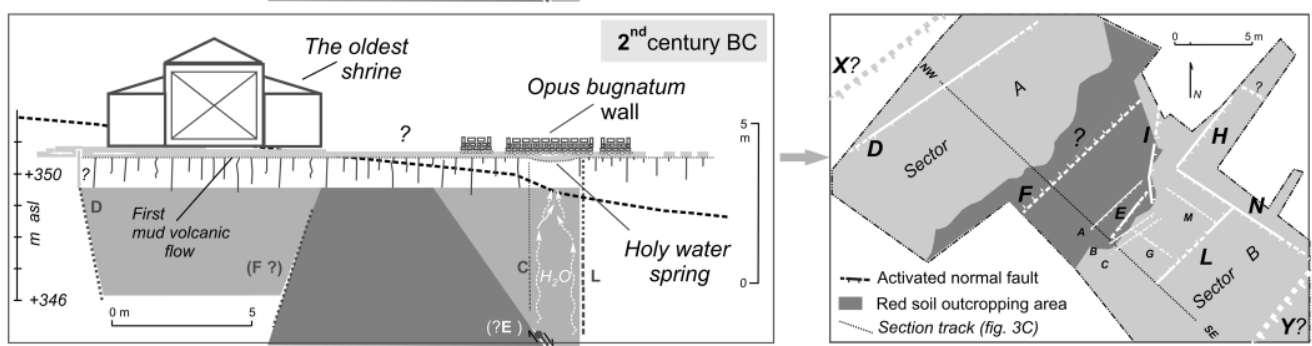

(b)

Figure 8. Section and plan location of the main recorded human settlements (left column) and deformation (right column) phases recognized in La Rovina di Montegibbio archaeological excavation. The suggested movements $( \pm)$ are only relative. The letters A-G indicate the relative chronology from bottom to top. The faults activated in each period are shown in black. The panels shown in $\mathrm{G}$ correspond to those of Figures $2 c$ and $3 a$, respectively. Between panels $F$ and $G$ the existence of a new building dating back to the 5 th-6th century $A D$ is omitted. The maximum slope downthrown is shown in panel $\mathrm{E}$. 

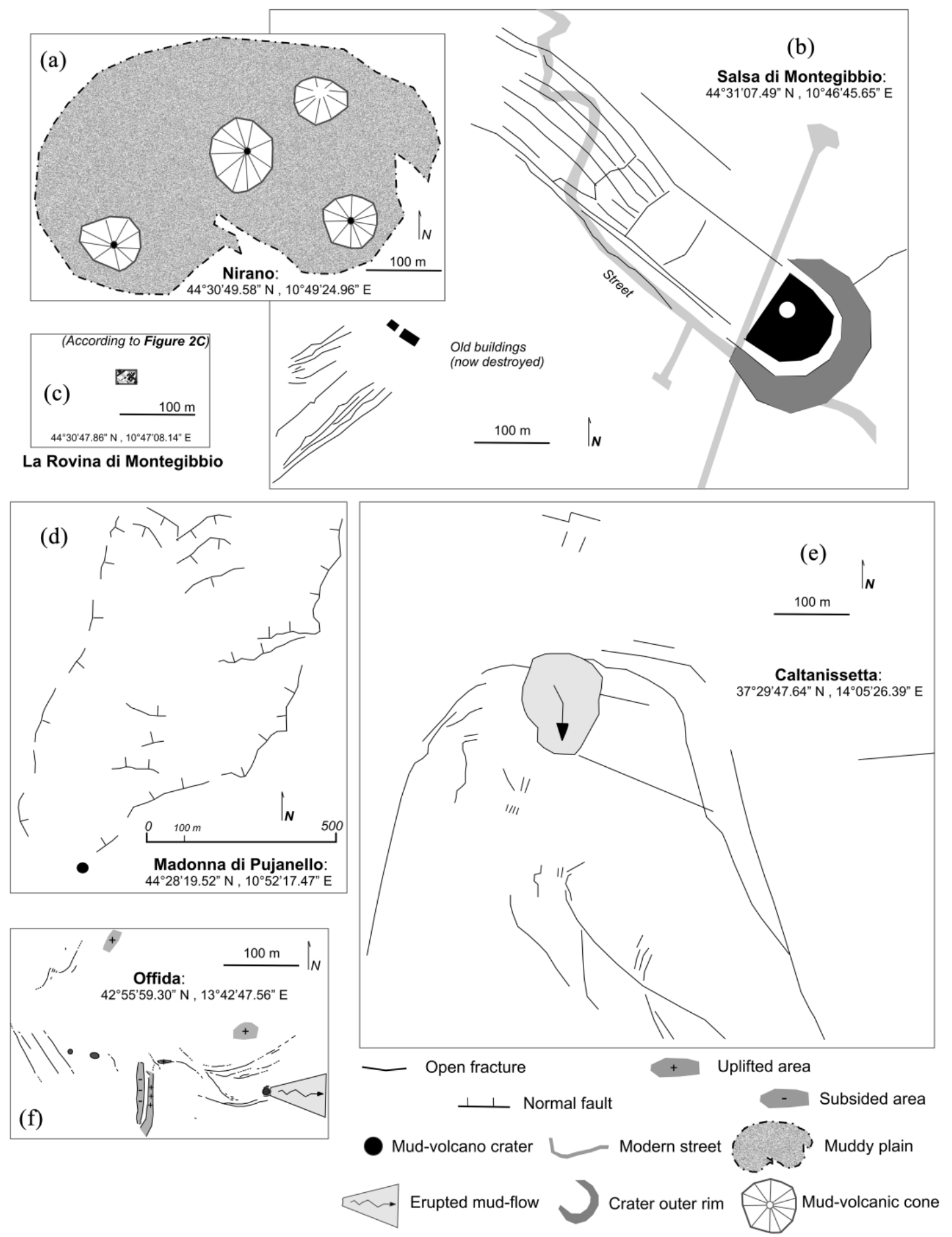

Figure 9. Map of ground deformation developed during single mud eruptions around some Italian mud volcanoes. (a) Nirano. (b) Montegibbio (12). (c) La Rovina di Montegibbio site. (d) Madonna di Pujanello (20). (e) Caltanissetta (18). (f) Offida (17). The scale bar is the same for all except (c), whose scale is halved. In (c), the actual size is that of the central small rectangle.

and brackish waters gushed from the ground over a few days (Figure 6 and Table 3 in Supplementary materials, available online). After the eruption, the spring dried up, but some days later, it erupted again some metres from the backyard of the Bath buildings. On this occasion, methane degassing bubbles were observed, and the amount of marine environment-derived ions was significantly higher than previously observed. After several weeks, the eruption decreased again (Figure 10). This recent short-term phenomenon confirms that the Montegibbio mud-volcanic system is still active and could originate eruptions with fluid expulsion in the future. Similar activity could have occurred 20 centuries ago, damaging the Minerva shrine, even in the absence of seismic activity. The geochemical features of mud-volcanic waters, Salvarola spa and the Rio Petrolio area are similar (Camerana and Galdi, 1911). In particular, the waters are chlorinedominated groundwaters originating from brines linked to hydrocarbons. These brines have interacted with host rocks and occasionally also with meteoric waters (Boschetti et al., 2015). The previously discussed B isotope ratios confirm the possible link between whitish layers originating from mud-volcanic activity and a marine environment (Martinelli et al., 2018; Pennisi et al., 2013a). Detailed location of minor mud volcanoes emitting fluids along the mountain chain is shown in Figure 1 and suggests that deep hydrocarbons and associated brackish waters may reach the topographic surface through various kinds of ascent pathways generated by the local tectonic setting acting in a complex and 


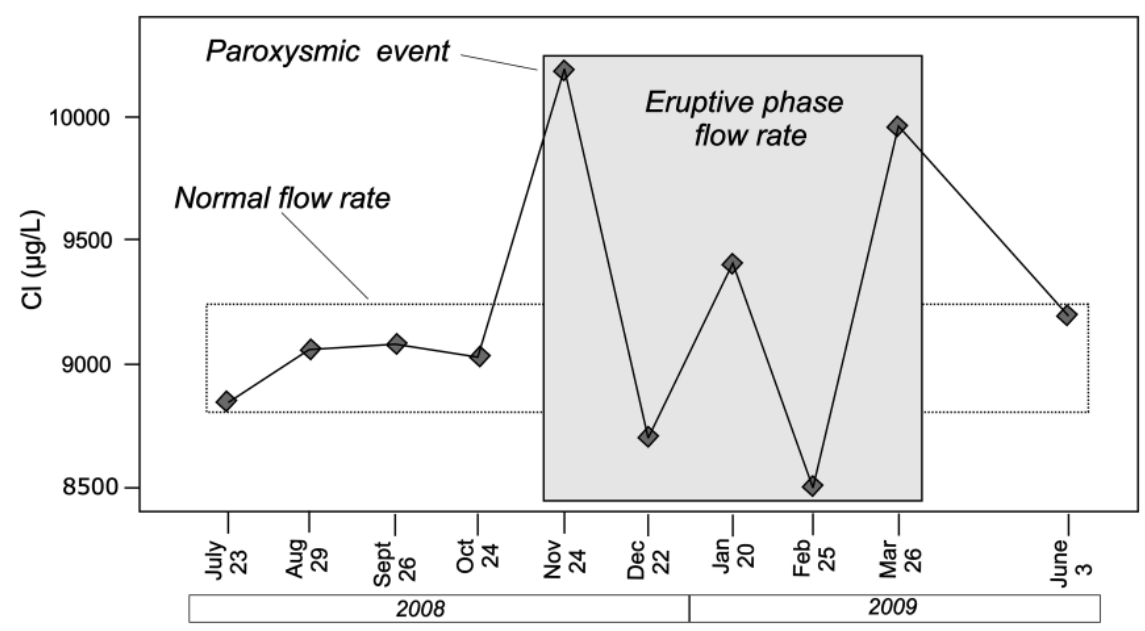

Figure 10. Chlorine concentration through the 2008-2009 period at the Salvarola Bath site.

repetitive manner through space and time. The general geometry of the fault plane sets in Figure 5 (the Salsa di Montegibbio main mud volcano) is quite different from that of Figure 4 (La Rovina di Montegibbio archaeological site). In Figure 4, the fault planes are lystric, and their attitude is consistent with a family of faults recorded in the same area by Castaldini et al. (2017). For these reasons, it can be thought that the whitish mud emissions could have resulted from the functioning of a distal system of mutually interplaying faults able to convey materials during intermittent and scattered small-scale mud-volcanic activity rather than a single, large mud volcano crater and related structures at the surface and at depth. Furthermore, taking into account the relationships existing between earthquake magnitude and the induced related surficial morphologies (McCalpin, 1996), size, geometry and development chronology of faults recorded in Figure 4 cannot fit with any historical earthquake known in the geographical area (Bonini, 2008; Guidoboni et al., 2007). For all these reasons, the mudflow layers and the series of recorded deformations could retain the surficial response to the evolution of a larger and more complex mud volcano system, the Montegibbio mud volcano, located $700 \mathrm{~m}$ from the archaeological site and $70 \mathrm{~m}$ lower than La Rovina di Montegibbio archaeological site.

\section{Conclusion}

Based on field and analytical data, we unravelled the recent evolution of an upper hillslope in relation to a previously unknown relatively small and distal structure linked to the larger Montegibbio mud-volcanic system in the northern Apennines of Italy. This study was possible thanks to the existence of an archaeological site we used as a high-resolution geological marker. In particular, the mud volcano environment, with active cones and springs, is considered the cause of both the onset and the abandonment of a sacred Roman-age site dedicated to the goddess Minerva. A combination of mud volcanism sensu stricto and surficial active mud volcano tectonics can be inferred. In fact, during the repeated ground deformation phases affecting the area, of the two whitish mudflows recorded in the archaeological sequence, the first subsided together with the natural red Alfisol and all the archaeological structures, whereas the second flowed even into the box-like central collapsed area from its periphery. To date, no traces of an elliptical morphology eventually linked to a collapse caldera (Bonini, 2008; Bonini et al., 2016) can be recognized in the landscape. At the same time, the tectonic setting cannot be connected to a wider neotectonic setting (e.g. Bankwitz et al., 2003). Considering the ongoing low-rate activity of the Apenninic mud volcano belt (Manga and Bonini, 2012), the recorded dormant fault set intersecting the topographic surface could be linked to a deeper and larger scale fault system reaching a depth of several hundred metres. When the fault system moves, fluids originating from a deeper reservoir are eventually able to seep, following fuzzy pathways that are variable through time over large areas and may activate, deactivate or even change the nature of emissions from springs to mud cones and to explosive mud volcanoes.

\section{Acknowledgements}

Thanks are to be given to Soprintendenti ai Beni Archeologici of Emilia-Romagna Region F.M. Gambari, M.E. Minoja, L. Malnati; A. Bertini for pollen checking; F. Benassi and S. Scaruffi for archaeological excavation and interpretation; and a mother who passed away at the end of the excavations. We wish also to thank members of the local community: Circolo Boschetti Alberti di Montegibbio; Gruppo Archeologico di Montegibbio; archaeologists and honorary inspectors: C. Baraldi, A. Manicardi, T. Previdi, and I. Zaccarelli; and students from Modena, Reggio Emilia and Bologna universities: G. Sfargeri, P. Bonometti, A. Bosi, C. Bussotti, G. Cantergiani, G. Ferrari, S. Iorio, E. Nardelli, C. Osetta, P. Romani, S. Sala, A. Selmi, C. Simonini, and M. Veratti. Finally, thanks are also due to Bonaposta D. for the photograph in Figure 4 of the Supplementary materials, available online. G. Martinelli was partially supported by the Chinese Academy of Sciences Visiting Professorship for Senior International Scientists (2018VMA0007). BL performed geology, geomorphology and seismic line interpretation; BG and MMC performed pollen analysis; BEA, MG and PD performed geophysical field surveys; CS performed geology, geomorphology, geoarchaeology, seismic lines interpretation and the drawing of figures; FG and MG performed geochemical analyses; GF and LD performed archaeological excavation data and their interpretation; MG drafted the discussion on mud volcanism; and BL and CS. drafted the remainder of the text. The authors thank the two anonymous reviewers and the editor A. Dawson who improved the text.

\section{Funding}

The research was funded by RFO-MIUR (ex 60\%) 2010, 2011, 2012 and 2013 (person in charge: LB); RFO-MIUR (ex 60\%) 2011 and 2012 (person in charge: SC); Comune di Sassuolo (2006-2015); Fondazione Cassa di Risparmio di Modena (2014); Contributions from Manfredini \& Schianchi Sassuolo, C.B.C. Group Pigneto and Centro Carni Sassuolo.

\section{Supplemental material}

Supplemental material for this article is available online. 


\section{ORCID iDs}

Borgatti Lisa (iD httnc///orcid.org/0000-0001-5407-8362

Martinelli Giovanni (iD https://orcid.org/0000-0001-9541-5142

\section{References}

Accaino F, Bratus A, Conti S et al. (2007) Fluid seepage in mud volcanoes of the northern Apennines: An integrated geophysical and geological study. Journal of Applied Geophysics 63(2): 90-101.

Anderberg AL (1994) Atlas of Seeds. Part 4. Resedaceae-umbelliferae. Stockholm: Swedish Museum of Natural History.

Antonielli B, Monserrat O, Bonini M et al. (2015) Pre-eruptive ground deformation of Azerbaijan mud volcanoes detected through satellite radar interferometry (DInSAR). Tectonophysics 637: 163-177.

Bankwitz P, Bankwitz E, Bräuer K et al. (2003) Deformation structures in Plio- and Pleistocene sediments (NW Bohemia, Central Europe). In: Van Rensbergen P, Hillis RR, Maltman AJ et al. (eds) Subsurface Sediment Mobilization. London: Geological Society of London.

Barker P (1993) Techniques of Archaeological Excavation. London: Routledge.

Barth S (1993) Boron isotope variations in nature: A synthesis. Geologischerundschau 82(4): 640-651.

Berggren G (1981) Atlas of Seeds. Part 3. Salicaceaee-cruciferae. Stockholm: Swedish Museum of Natural History.

Bertini A (2010) Pliocene to Pleistocene Palynoflora and vegetation in Italy: State of the art. Quaternary International 225(1): 5-24.

Bertolini G and Sartini G (2001) La frana di Valestra (Comune di Carpineti, Provincia di Reggio Emilia). Quaderni di Geologia Applicata 8: 195-215.

Bertolini G, Guida M and Pizziolo M (2005) Landslides in Emilia-Romagna region (Italy): Strategies for hazard assessment and risk management. Landslides 2(4): 302-312.

Biasutti R (1907) Materiali per lo studio delle salse-Le salse dell'AppenninoSettentrionale. Memoriegeografiche, Pubblicate Come Supplemento Alla Rivista Geografica Italiana da Giotto Dainelli 2: 101-255.

Boccaletti M, Corti G and Martelli L (2011) Recent and active tectonics of the external zone of the Northern Apennines (Italy). International Journal of Earth Sciences 100(6): 1331-1348.

Bonaposta D and de Nardo MT (2017) Attivazioni storicamente documentate delle Salse del margine appenninico modenese e reggiano. Atti Società Matematici Naturalisti Modena 148: 59-68.

Bonini M (2008) Elliptical mud volcano caldera as stress indicator in an active compressional setting (Nirano, Pede-Apennine margin, northern Italy). Geology 36(2): 131-134.

Bonini M (2009) Mud volcano eruptions and earthquakes in the Northern Apennines and Sicily, Italy. Tectonophysics 474(34): 723-735.

Bonini M (2012) Mud volcanoes: Indicators of stress orientation and tectonic controls. Earth-Science Reviews 115(3): $121-152$.

Bonini M, Rudolph ML and Manga M (2016) Long- and shortterm triggering and modulation of mud volcano eruptions by earthquakes. Tectonophysics 672-673: 190-211.

Boschetti T, Toscani L and Mariani ES (2015) Boron isotope geochemistry of Na-bicarbonate, Na-chloride, and Ca-chloride waters from the Northern Apennine Foredeep basin: Other pieces of the sedimentary basin puzzle. Geofluids 15(4): 546-562.

Bruno B (2012) Marano di valpolicella, Montecastelon. La campagna di scavo 2010 nell'area del santuario di Minerva. Quaderni di Archeologia del Veneto 28: 96-100.

Camerana E and Galdi B (1911) I giacimenti petroliferi dell'Emilia. Memorie Descrittive della Carta Geologica d'Italia 14: 335.
Camerana E, Cotese E, Crema C et al. (1926) Studigeologici per la ricerca del petrolio in Italia. Memorie Descrittive Della Carta Geologica D'italia 20: 1-288.

Capozzi R and Picotti V (2002) Fluid migration and origin of a mud volcano in the Northern Apennines (Italy): The role of deeply rooted normal faults. Terra Nova 14(5): 363-370.

Cappers RTJ, Bekker RM and Jans JEA (2006) Digitale Zadenatlas van Nederland. Groningen: Barkhuis Publishing and Groningen University Library.

Casoli S (2001) Su un fenomeno naturale descritto da Plinio (Nat. Hist. 2, 199) accaduto nel territorio modenese. Atlante Tematico di Topografia Antica 10: 63-70.

Castaldini D, Coratza P and de Nardo MT (2017) Geologia e geomorfologia delle Salse di Nirano. Atti Società Matematici Naturalisti Modena 148: 23-58.

Cinti FR, Alfonsi L, D'Alessio A et al. (2015) Faulting and ancient earthquakes at sybaris archaeological site, Ionian Calabria, southern Italy. Seismological Research Letters 86(1): 245-254.

Costa C, Monelli D, Morgana S et al. (2008) Emergenza 'maccalube' dell'11 agosto 2008 nel Comune di Caltanissetta. Descrizione dell'evento e dei danni. Available at: http://www. regione.sicilia.it/presidenza/protezionecivile/documenti/documenti/Maccalube_2008.pdf (accessed 5 December 2018).

Cremaschi M (1979) Alcune osservazioni sul paleosuolo delle conoidi 'würmiane' poste al piede dell'Appennino emiliano. Geografia Fisica e Dinamica Quaternaria 2: 187-195.

Cremonini G and Farabegoli E (1977) Litostratigrafia della Formazione a Colombacci in Romagna. Giornale di Geologia 62: 61-82.

Cremonini S, Falsone G, Marchesini M et al. (2012) Suoli olocenici sepolti nell'Emilia orientale - Holocene buried soils in Eastern Emila Region. EQA 1: 107-121.

Cremonini S, Labate D and Curina R (2013) The late-antiquity environmental crisis in Emilia region (Po river plain, Northern Italy): Geoarchaeological evidence and paleoclimatic considerations. Quaternary International 316: 162-178.

Curina R and Cremonini S (2010) Possibili evidenze cosismiche di etàromana presso Bologna. Quaderni di Archeologia Dell'emilia Romagna 26: 117-132.

Damiani AV (1964) Studio della salsa di Offida (Ascoli Piceno - Marche). L'Universo 44(3): 473-488.

Del Monaco G, Margottini C and Spizzichino D (2009) Lowimpact interventions for the preservation of cultural heritage: The dying town of Civita di Bagnoregio (Central Italy) and the killer landslide protection of historical buildings. In: Mazzolani FM (ed.) Protection of Historical Buildings. Rome: Prohitec, pp. 1455-1459.

Deville E, Battani A, Griboulard R et al. (2003) The origin and processes of mud volcanism: New insights from Trinidad. Geological Society (London: Special Publications) 216(1): 475-490.

Deyhle A, Kopf AJ and Aloisi G (2003) Boron and boron isotopes as tracers for diagenetic reactions and depth of mobilization, using muds and authigenic carbonates from eastern Mediterranean mud volcanoes. Geological Society (London: Special Publications) 216(1): 491-503.

Doderlein P (1867) La sorgente salso-jodica della Salvarola presso Sassuolo: memoria storica-geognostica. Atti Reale Accademia Scienze Lettere Arti di Modena 3: 37-64.

Ekenwalder JE (2009) Conifers of the World. Portland, OR: Timber Press.

FAO (2014) World reference base for soil resources: World Soil Resources Report. Rome: FAO. Available at: http://www.fao. org/3/i3794en/I3794en.pdf.

Florenzano A, Mercuri AM, Pederzoli A et al. (2012) The significance of intestinal parasite remains in pollen samples from medieval pits in the piazza garibaldi of parma, Emilia Romagna, northern Italy. Geoarchaeology 27(1): 34-47. 
Galadini F and Galli P (1999) Palaeoseismology related to the displaced Roman archaeological remains at Egna (Adige Valley, northern Italy). Tectonophysics 308(1-2): 171-191.

Galadini F, Hinzen KG and Stiros S (2006) Archaeoseismology: Methodological issues and procedure. Journal of Seismology 10(4): 395-414.

Galli P, Messina P, Giaccio B et al. (2012) Early Pleistocene to Late-Holocene activity of the Magnola fault (fucino fault system, central Italy). Bollettino di Geofisica Teorica ed Applicata 53(4): 435-458.

Gasperi G, Bettelli G, Panini F et al. (2005) Note Illustrative della Carta Geologica d'Italia alla Scala 1:50.000 (Fogli No. 219). Firenze: Sassuolo.

Goldberg P and Macphail RI (2006) Practical and Theoretical Geoarchaeology. Oxford: Blackwell.

Govi S (1906) Appunti su alcune salse e fontane ardenti della provincia di Modena. Rivista Geografica Italiana 13: 425-431.

Grimm EC (2004) Tgview Version 2.0.2. Springfield, IL: Illinois State Museum Research Collection Center.

Guandalini F (2009) Gli scavi dell'insediamento di Montegibbio. Quaderni di Archeologia dell'Emilia Romagna 26: 31-58.

Guidoboni E (2010) Le tracce di terremoti in archeologia e il dialogo multidisciplinare: l'insediamento di Montegibbio come laboratorio pilota? Quaderni di Archeologia dell'Emilia Romagna 26: 111-116.

Guidoboni E and Ebel J (2009) Earthquakes and Tsunamis in the past. Cambridge, MA: Cambridge University Press.

Guidoboni E, Ferrari G, Mariotti D et al. (2007) CFTI4MED, Catalogue of Strong Earthquakes in Italy 461 BC-1997 AD and Mediterranean Area 760 BC-1500 AD. Available at: storing.ingv.it/cfti4med (accessed 5 December 2018).

Guliyev IS and Huseynov DA (2015) Relics of mud volcanoes in the sedimentary cover of the South Caspian Basin. Lithology and Mineral Resources 50(4): 311-321.

Harris EC (1989) Principles of Archaeological Stratigraphy. New York: Academic Press.

Higgins GE and Saunders JB (1974) Mud volcanoes, their nature and origin. Verhandlungen Naturforshenden Geselschaft in Basel 84: 101-152.

Hovland M, Hill A and Stokes D (1997) The structure and geomorphology of the Dashgil mud volcano, Azerbaijan. Geomorphology 21(1): 1-15.

Iaccarino S and Papani G (1980) Il Messiniano dell'Appennino settentrionale dalla Val d'Arda alla Val Secchia: stratigrafia e rapporti con il substrato e il Pliocene. In: Venzo S (ed.) Scritti degli Istituti di Geologia, Paleontologia, Geografia, Petrografia e Giacimenti Minerari, Mineralogia. Parma: STEP, pp. 15-46.

Kaplan DI, Adriano DC, Mills GL et al. (1990) Determination of boron in soils containing inorganic and organic boron sources. Soil Science Society of America Journal 54(3): 708-714.

Kopf AJ (2008) Making calderas from mud. Nature Geoscience 1(8): 500-501.

Larini G, Malaguti C, Pellegrini M et al. (2001) La lama di Corniglio (Appennino parmense) riattivata negli anni 19941999. Quaderni Geologia Applicata 8: 59-114.

Luongo G, Perrotta A and Scarpati C (2003) Impact of the AD 79 explosive eruption on Pompeii, I. Relations amongst the depositional mechanisms of the pyroclastic products, the framework of the buildings and the associated destructive events. Journal of Volcanology and Geothermal Research 126(3-4): 201-223.

Lupi M, Ricci BS, Kenkel J et al. (2015) Subsurface fluid distribution and possible seismic precursory signal at the Salse di Nirano mud volcanic field, Italy. Geophysical Journal International 204(2): 907-917.

McCalpin JP (1996) Paleoseismology. San Diego, CA: Academic Press.

Madonia P, Grassa F, Cangemi M et al. (2011) Geomorphological and geochemical characterization of the 11 August 2008 mud volcano eruption at S. Barbara village (Sicily, Italy) and its possible relationship with seismic activity. Natural Hazards and Earth System Science 11(5): 1545-1557.

Manga M and Bonini M (2012) Large historical eruptions at subaerial mud volcanoes, Italy. Natural Hazards and Earth System Sciences 12(11): 3377-3386.

Manga M, Brumm M and Rudolph ML (2009) Earthquake triggering of mud volcanoes. Marine and Petroleum Geology 26(9): 1785-1798.

Martinelli G and Judd A (2004) Mud volcanoes of Italy. Geological Journal 39(1): 49-61.

Martinelli G and Panahi B (2005) Mud volcanoes. Geodynamics and seismicity. NATO Science Series IV. Earth and Environmental Sciences 51: 288.

Martinelli G, Castagna M and Pennisi M (2014) Il monitoraggio del Boro nel sito contaminato nazionale Sassuolo-Scandiano (area del distretto ceramico di Modena e Reggio Emilia). In: Farina M, Marcaccio M and Zavatti A (eds) Esperienze e prospettive nel monitoraggio delle acque sotterranee: Il Contributo dell'Emilia-Romagna. Bologna: PitagoraEditrice Bologna, pp. 406-412.

Martinelli G, Cremonini S and Samonati E (2012) Geological and geochemical setting of natural hydrocarbon emissions in Italy. In: Al-Megren HA (ed.) Advances in Natural Gas Technology. Rijeka, Croatia: InTech, pp. 79-120.

Martinelli G, Dadomo A, de Luca DA et al. (2018) Nitrate sources, accumulation and reduction in groundwater from Northern Italy: Insights provided by a nitrate and boron isotopic database. Applied Geochemistry 91: 23-35.

Mazzini A and Etiope G (2017) Mud volcanism: An updated review. Earth-Science Reviews 168: 81-112.

Mellors R, Kilb D, Aliyev A et al. (2007) Correlations between earthquakes and large mud volcano eruptions. Journal of Geophysical Research: Solid Earth 112(B4): B04304.

Montecchi MC and Accorsi CA (2010) Analisi pollinica di saggio al sito di Montegibbio-Villa romana, I e III-IV sec. d.C. In: Guandalini $\mathrm{F}$ and Labate D (eds) L'Insediamento di Montegibbio, una ricerca interdisciplinare per l'archeologia. Firenze: All'Insegna del Giglio, pp. 83-88.

Moore PD, Webb JA and Collison ME (1991) Pollen Analysis. Oxford: Blackwell.

Mulas M, Bayer B, Bertolini G et al. (2016) Impulsive ground movements in the mud volcanoes area of 'Le Sarse' di Puianello (Northern Apennines, Modena, Italy): Field evidence and multi-approach monitoring. Rendiconti on Line della Società Geologica Italiana 41: 251-254.

Oppo D, Capozzi R and Picotti V (2013) A new model of the petroleum system in the Northern Apennines, Italy. Marine and Petroleum Geology 48: 57-76.

Pantanelli D (1900) Su alcuni errori di fatto circa le salse modenesi e il petrolio d'Egitto. Bollettino Società Geografica Italiana 1: $1021-1026$

Pearsall DM (2015) Paleoethnobotany: A Handbook of Procedures. Walnut Creek, CA: Left Coast Press.

Pennisi M, Adorni-Braccesi A, Andreani D et al. (2013a) Isobordat: An online database on boron isotopes. In: Proceedings from an International Symposium on Isotopes in Hydrogeology, Marine Ecosystems and Climate Change Studies (IAEACN-186/61), Monaco, 27 March-1 April, pp. 381-388. Wien: International Atomic Energy Agency.

Pennisi M, Battaglia S and Martinelli G (2013b) Mineralogy and Boron geochemistry of mud volcanoes from Northern Apennines (Italy). In: Goldschmidt 2013 Conference Abstracts, 1947. Available at: https://goldschmidtabstracts.info/abstracts /abstractView?id=2013004492

Picotti V, Ponza A and Pazzaglia FJ (2009) Topographic expression of active faults in the foothills of the Northern Apennines. Tectonophysics 474(1-2): 285-294. 
Planke S, Svensen H, Hovland M et al. (2003) Mud and fluid migration in active mud volcanoes in Azerbaijan. Geo-Marine Letters 23(3-4): 258-268.

Punt W and Clarke GCS ([1980] 1981) The Northwest European Pollen Flora, II, III, IV, V. Amsterdam: Elsevier.

Punt W, Blackmore S and Hoen PP (1995) The Northwest European Pollen Flora, VII. Amsterdam: Elsevier.

Punt W, Blackmore S, Hoen PP et al. ([2003] 2009) The Northwest European Pollen Flora, VIII, IX. Amsterdam: Elsevier.

Punt W, Janssen CR, Reitsma TJ et al. (1976) The Northwest European Pollen Flora. Amsterdam: Elsevier.

Reimer PJ, Bard E, Bayliss A et al. (2013) IntCal 13 and marine 13 radiocarbon age calibration curves $0-50,000$ years cal BP. Radiocarbon 55(4): 1869-1887.

Rinaldi R, Bosi G and Mozzanti MB (2010) Prime analisi carpologiche nelsito di Montegibbio. Quaderni di Archeologia dell'Emilia Romagna 26: 77-81.

Rossi F (2010) Il Santuario di Minerva: Luogo di culto a Breno tra protostoria ed età Romana. Milano: Edizioni ET.

Scicli A (1972) L'attività Estrattiva e le Risorse Della Regione Emilia Romagna. Modena: Poligrafico Artioli.

Sdao F and Simeone V (2007) Mass movements affecting Goddess Mefitis sanctuary in Rossano di Vaglio (Basilicata, southern Italy). Journal of Cultural Heritage 8(1): 77-80.

Serra O (1986) Fundamentals of Well-log Interpretation 2: The Interpretation of Logging Data. Amsterdam: Elsevier.
Somoza L, Medialdea T, León R et al. (2012) Structure of mud volcano systems and pockmarks in the region of the Ceuta Contourite depositional system (western Alborán Sea). Marine Geology 332-334: 4-26.

Stewart IS and Piccardi L (2017) Seismic faults and sacred sanctuaries in Aegean antiquity. Proceedings of the Geologists' Association 128(5-6): 711-721.

Stiros S and Jones RE (1996) Archaeoseismology (Fitch Laboratory Occasional Papers). Athens: British School at Athens, p. 268.

Stöhr E (1867) Schiarimenti intorno alla carta delle Salse e delle località oleifere di Monte Gibio. Annuario della Società dei Naturalisti in Modena 2: 169-178.

Stoops G (2003) Guidelines for Analysis and Description of Soil and Regolith Thin Sections. Madison, WI: Soil Science Society of America.

Stumm W and Morgan JJ (1996) Aquatic Chemistry: Chemical Equilibria and Rates in Natural Waters. New York: John Wiley \& Sons.

Taylor TN, Taylor EL and Krings M (2009) Paleobotany: The Biology and Evolution of Fossil Plants. New York: Academic Press.

Vengosh A and Spivack AJ (2000) Boron isotopes in groundwater. In: Cook PG and Herczeg AL (eds) Environmental Tracers in Subsurface Hydrology. New York: Springer, pp. 479-510.

$\mathrm{Xu} \mathrm{C}$, Ma S, Tan Z et al. (2018) Landslides triggered by the $2016 \mathrm{Mj}$ 7.3 Kumamoto, Japan, earthquake. Landslides 15(3): $551-564$. 